Medievalia 23/I (2020), 33I-393 - ISSN: 20I4-84Io (digital)

DOI: https://doi.org/I0.5565/rev/medievalia. 498

\title{
MOVEMENT ON THE ALTAR: \\ GOTHIC TABERNACLE-ALTARPIECES \\ IN THE CROWN OF ARAGON (AND THEIR CONTEXT)*
}

\author{
MOVIMIENTO SOBRE EL ALTAR: \\ LOS RETABLOS-TABERNÁCULO GÓTICOS \\ EN LA CORONA DE ARAGÓN (Y SU CONTEXTO)
}

\author{
Alberto Velasco Gonzàlez \\ Universitat de Lleida \\ alberto.velasco@hahs.udl.cat \\ https://orcid.org/oooo-0003-46II-0339
}

Received: 29/II/2019 - Accepted: 23/OI/2020

\begin{abstract}
The arrival of tabernacle-altarpieces in regions under the Crown of Aragon makes up part of a complex context revolving around the evolution of altar furnishings from the late Romanesque to the early Gothic period. The late $13^{\text {th }}$ century and first half of the $14^{\text {th }}$ century saw a series of fundamental movements - changes prior to the verticalization of altarpieces. All of this took place at the same time that specific types of altar furnishing that already existed during the Romanesque, such as those presenting a sculptural image inside a tabernacle, became steeped in new features, and evolved by taking on movable wings at the sides which could be ritually opened up. This lent them a certain theatricality and the ability to conceal and reveal, while also allowing for processes activating the central image presiding over them. These, specifically, are some of the main contributions of tabernacle-altarpieces to the history of Christian altar furnishing. In the Crown

* This article is part of the results of the 'Expresividad, sentimiento y emoción (siglos XII-XV)' project (Ministry of Economy, Industry and Competitiveness, Government of Spain, ref. HAR2or675028-P, main researcher: Dr. Flocel Sabaté), as well as of the Consolidated Research Group on Medieval Studies 'Espai, Poder i Cultura', recognised by the Catalan Regional Government (ref. 2017 SGR 43, main researcher: Dr. Flocel Sabaté). I would, finally, like to express my thanks to Fernando Gutiérrez Baños and Justin Kroesen for their critical reading of this text, which they enriched with their suggestions and comments.
\end{abstract}


of Aragon, this type of furnishing does not appear to have become very widespread, given that we only have documentary evidence of it in Catalonia and Aragon. All the same, the exemplars that have survived respond to models and types that exactly match those found throughout the kingdom of Castile and the rest of Europe, both those presenting sculptural reliefs on their wings and those with pictorial representations. Finally, we should point out that their chronological presence spanned practically the entire Gothic period, from the early Linear Gothic years until well into the $15^{\text {th }}$ century.

\section{Keywords}

Tabernacle-altarpieces, Gothic art, Gothic sculpture, Gothic painting, art and liturgy, Crown of Aragon, Catalonia, Aragon, Pyrenees.

\section{Resumen}

La llegada de los retablos-tabernáculo a los territorios de la Corona de Aragón forma parte de un complejo contexto que gira en torno a la evolución del mobiliario de altar desde el último románico hasta la llegada del primer gótico. Desde finales del siglo XIII y durante la primera mitad del XIV asistiremos a una serie de movimientos — cambios - trascendentales que fueron anteriores a la verticalización de los retablos. Todo ello se produjo al mismo tiempo que determinadas tipologías de muebles de altar ya existentes durante el románico, como aquellas que presentaban una imagen escultórica dentro de un tabernáculo, se empapaban de las novedades y evolucionaban al incorporar alas móviles en los extremos que permitían aperturas rituales. Ello las dotaba de teatralidad y de la capacidad de velar y desvelar, a la vez que permitía procesos de activación de la imagen central que las presidía. Estas son, precisamente, algunas de las principales aportaciones de los retablos-tabernáculo a la historia del mobiliario del altar cristiano. En la Corona de Aragón, este tipo de muebles parece ser que no tuvieron una difusión generalizada, puesto que solamente los documentamos en Cataluña y Aragón. Los ejemplares conservados, con todo, responden a modelos y tipologías plenamente afines a las difundidas en el reino de Castilla y en el resto de Europa, tanto aquellos que presentaban relieves escultóricos en sus alas, como los que mostraban decoraciones pictóricas en ellas. Hay que señalar, finalmente, que su presencia cronológica abarca casi todo el período gótico, desde los primeros tiempos del gótico lineal, hasta bien entrado el siglo xv.

\section{Palabras clave}

Retablos-tabernáculo, arte gótico, escultura gótica, pintura gótica, arte y liturgia, Corona de Aragón, Cataluña, Aragón, Pirineos. 
In this article, we will be analysing a type of altar furnishing broadly known across Europe as 'tabernacle-altarpieces'. As is known, these pieces included a central tabernacle crowned by a canopy housing a sculptural image over which four movable side wings would normally close, either painted or with polychrome sculptural reliefs (Frinta, 1967; Lapaire, 1969; Andersen, 2015; Gutiérrez Baños, 20I8). One of the most marked aspects of this type of furnishing is how widespread it became in a large portion of the European continent, with documented works in countries such as Italy, France, Germany, Switzerland, Norway, Sweden, Slovakia and Denmark as of the $12{ }^{\text {th }}$ and $13{ }^{\text {th }}$ centuries (Kroesen, 20I4a, p. I63). The most representative surviving ensemble is from Sweden (Tångeberg, 2009), where examples from the $14^{\text {th }}$ century predominate, some of which are extremely similar to the few exemplars that have survived from the old Crown of Aragon. The fact that no sufficiently representative group has come down to us from the latter region may be due to two causes. Firstly, the structural fragility of these pieces and, moreover, their being replaced as a result of changing tastes and the advent of large-scale altarpieces in the $14^{\text {th }}$ and $15^{\text {th }}$ centuries, as was also the case in other parts of Europe (Frinta, 1967, p. 105).

One of the questions we should be asking ourselves today is whether these tabernacle-altarpieces were equally present in Aragon, Catalonia, Valencia and Mallorca; that is to say, the different regions making up the old Crown of Aragon. Judging by the surviving exemplars and what we can glean from the documentation, we can conclude that this was not the case. One of the conclusions of the study we are putting forward here is that their presence in Valencia and Mallorca must have been at most residual, or even non-existent. ${ }^{\mathrm{I}}$ Not a single work has survived from those areas, and we know of no clear documentary reference alluding to tabernacle-altarpieces with movable wings from either location. ${ }^{2}$ And we ought to be asking ourselves why that should be the case, as recent studies have shown that in areas such as Valencia Linear Gothic mural painting was more

' Even though it has not been possible for us to carry out a physical inspection of a set of two panels kept in the monastery of Santa Clara of Palma, on the island of Mallorca, to determine if they have traces of hinges, we should at least mention them as possible wings from a tabernacle-altarpiece of the middle of the $\mathrm{I}_{4}^{\text {th }}$ century. They show episodes of the Passion on the interior and stars and two heraldic shields (not identified) on the exterior. See Gaita, I999.

${ }^{2}$ References do exist that are difficult to interpret due to the polysemy of the term 'tabernacle' during the middle ages in the Crown of Aragon, and we will return to this matter later. For example, in 1348 the painter Beló charged I8 sueldos 'per lo tabernacle que fo on estava lo retaule de madona Senta Maria a la salla', from the house in the city of Palma (Llompart, I977-80, vol. 4, p. 52, doc. 70). 
widely present than we had supposed until recently (Rubio/Zalbidea, 2019). As is known, this is a pictorial style developed between the late $13^{\text {th }}$ century and the first third of the $14^{\text {th }}$ century, at a time when the type of furnishing we are studying here was emerging, and as such both the Crown of Aragon and that of Castile produced a range of tabernacle-altarpieces executed in said style. If that artistic language was present in the churches of Valencia, and was adapted for mural painting and a number of wooden ceilings, why is it that there is no surviving trace of tabernacle-altarpieces in said area? This may be the result of the vicissitudes of history or the twists of fate, but it is possible that this sort of furnishing never became equally widespread across all the territories under the Crown of Aragon.

\section{MOVEMENT ON THE ALTAR AND ALTAR FURNISHINGS IN MOVEMENT}

One of the theories we will be arguing in this article is that the dissemination of tabernacle-altarpieces in specific areas of the Crown of Aragon was due to a series of innovations introduced as early as the $13^{\text {th }}$ century, and which continued to bloom throughout the $14^{\text {th }}$ century, in the context of the altar. In broad terms, this process underwent a succession of changes involving, for instance, the proliferation of free-standing Eucharistic tabernacles and their subsequent inclusion in the lower section of altarpieces, or the transferral of structural features between differing types of altar furnishing. The former meant the inclusion of Eucharistic chambers in the middle of the predella, which might include doors painted with Eucharistic subjects such as the Man of Sorrows. These movable features, which had an eminently practical and utilitarian function, were without doubt seen as elements encouraging not just the physical dynamism of the works, but also the devotional practices associated with them. This inclusion as part of the altar furnishing of elements that opened and closed, revealing and concealing, should be perceived as a not unambiguous phenomenon informing the choice of one type of furnishing or another depending on varying requirements, from the tastes of the patrons to worship necessities or the level of knowledge of innovative types of furnishing such as tabernacle-altarpieces.

Specifically, one of the main characteristics of the tabernacle-altarpiece was the ritual act of opening made possible by the movable wings. This gesture of revelation of whatever was contained inside is something it shares with other pieces of furnishing linked to worship, such as polyptychs, tabernacles and free-standing Eucharistic cabinets or shrines built into altarpieces. As Braun once com- 
mented, the movement of the wings or doors facilitated a change in the physical appearance of these furnishings (Braun, I924, II, pp. 355-357). In Catalonia this was an innovation with regard to the Romanesque period, as the few examples of known altar furnishings tended to have fixed wings, as seen in the aedicule of Sant Martí d'Envalls (Angostrina, Western Pyrenees, France), preserved today at the Centre d'Art Sacré d'Île-sur-Tet (Folch, I925; Delcor, I995; Le Pogam, 2009; Sureda, 2012, pp. 76-78; Kroesen, 20I4a, pp. I6I-I62, fig. 3). This furnishing including two fixed, painted side compartments as wings. What we have here, then, is clearly a forerunner of the Gothic tabernacle-altarpiece with movable panels. Judging by surviving pieces, one might conclude that the use of movable wings in the Crown of Aragon was a feature introduced on works linked with the Gothic style, ${ }^{3}$ given that its advent united different types of altar furnishings. All the same, one must bear in mind the fact that in certain European regions movement was already present in works from the Romanesque period. ${ }^{4}$

From a given moment onwards, the novelty of including doors or wings that allowed for performative movement and dynamic actions altering the perception of the work, concealing and then revealing its interior, must have constituted a boost to the conception and design of furnishing elements associated with altars. It is as such that the emergence, in the Crown of Aragon, of tabernacle-altarpieces, Eucharistic tabernacles and cabinets, or the inclusion of a shrine into the lower part of altarpieces may be considered part of a phenomenon whose goal was to inject dynamism into the actions of the celebrant, to go beyond the static furnishing of Romanesque period altars and present the sancta sanctorum of the presbytery as a place of liturgical and devotional experiences based on movement. All of these innovations took place within a timespan starting in the late $13^{\text {th }}$ century and going into the $14{ }^{\text {th }}$ century, coinciding with the popularisation of tabernacle-altarpieces in regions such as Catalonia and Aragon.

${ }^{3}$ With regards to the two wings of the tabernacle-altarpiece with depictions of the Virgin and Saint Joseph from the old Alexandre Soler i March collection (Barrachina, 1997), as well as the four from the Museu Nacional d'Art de Catalunya (inv. 6605I-66054) with the Epiphany Magi and the Virgin, from the Bosch i Catarineu collection (Llarás/Carabasa, 1994, pp. 444-445), both being of the movable type, these have been dated to between the $12^{\text {th }}$ and $13^{\text {th }}$ centuries, but we have serious doubts concerning their authenticity. We would argue the need for a technical study to certify their degree of originality. With regard to the two wings from Sant Martí Sarroca preserved at the Museu Nacional d'Art de Catalunya, these have also been dated to the Romanesque period (I ${ }^{\text {th }}$ century) (Alcoy, 1994, pp. 308-310), but in our opinion they are later works and should be considered Gothic, as we will see shortly.

${ }^{4}$ For more on this matter, see Justin Kroesen's article in this volume. 
In the case of the tabernacle-altarpiece, what we are dealing with are devices that allowed for visual interaction with the image in the central tabernacle through the process of opening and closing movable panels, encouraging revelations linked to the exaltation, veneration and unveiling of what was contained within. This anthropically-generated performative movement stood, therefore, as a trigger leading to meanings linked to divinity. ${ }^{5}$ One can even argue that the opening of the wings of a tabernacle-altarpiece generated the activation of the main image in the eyes of the faithful or the celebrant. And all of this thanks to movement acting like a light switch.

As we have already mentioned, the opening of the side wings is an action, a gesture, that tabernacle-altarpieces shared with furnishings of relatively similar structure, but given over to different worship-oriented purposes, such as Eucharistic cabinets. Be that as it may, the interior decoration presented by the cabinets still surviving today from Catalan parishes places us before a type of furnishing that goes beyond the mere function of receptacle or Eucharistic chamber. As such, the narrative provided by the interior scenes, with episodes linked to the Passion in some cases, was complemented with the presence of full-length saints on the doors. ${ }^{6}$ It would appear that, on occasions, decorative canopies may be included similar to those we find at the top of the central tabernacle of tabernacle-altarpieces, or those topped by spires from the tabernacles presiding over certain altarpieces. ${ }^{7}$ One contrasting variation on this sort of cabinet is the one we find in the impressive reliquary-cabinet from the monastery of Piedra (Zaragoza), preserved today in the Real Academia de la Historia (Madrid), which in its dimensions, doors and format is reminiscent of the altarpieces and, even more so, triptychs, of the time. This is a Eucharistic container dating from I390, containing a truly exceptional inscription on its panels, identifying the furnishing as 'Tabernaculo hoc vocabitur aula Deo [...]' (González Zymla, 2013).

5 There is more on this subject in the works included in Zchomelidse/Freni, eds, 20II. Cfr. Kessler, 20I4.

${ }^{6}$ The known and documented exemplars show that they were especially common in Northern Catalonia, as we can observe in the piece preserved at the Museu Nacional d'Art de Catalunya, which originated from Perpignan; in the work from Elna Cathedral, in the one purchased by Meadows Museum in Dallas, or in the remains preserve in Illa (Alcoy 2003; Domenge 2005; Favà, 2017, p. I30, figs I2-I5).

${ }^{7}$ We can observe this in the inventory of the assets of the painter Pere Baró (I388), from Perpignan, which mentions 'Un armari del corpus que's stat d'Eune ab una lanterna en sus' (Gudiol Cunill, [n. d.], p. II7). 
Much the same can be said for the shrine Madonnas which, on being opened, revealed holy stories and broadened the very image's panoply of meanings, with an interplay on what could, and could not, be seen (Katz, 20II). It is doubtless significant that this sort of Marian image originated in the region of Castile towards the end of the $13^{\text {th }}$ century and that, from there, it spread to the other side of the Pyrenees, as Melissa Katz observed (2010). With regards to the Crown of Aragon, there are no surviving works from said area, ${ }^{8}$ but we do know that in 1325 the painter and sculptor Ramón Torrent, who was residing in Zaragoza, had in his workshop 'Una ymagen de Santa Maria con la historia de figuras y la ymagen abierta' (Serrano Sanz, I918, p. I07). ' The document mentioning this sculpture is an inventory referring to multiple images that the artist was working on or had concluded, from which we can only conclude that his workshop was producing shrine Madonnas. The advent of this sort of sculpture with movable panels revealing its interior may therefore be dated to the same period we are discussing, when a process of interaction and exchange was taking place between different types of liturgical altar furnishings.

The context of the late $13^{\text {th }}$ and start of the next century is core to the panorama we are attempting to describe, and as such the leading role taken on by folding doors in different elements from liturgical furnishing should be conceived of as part of a more or less generalised phenomenon. The opening methods differed in each case, due to nuances conditioned by the nature of the work, but in essence the nature of the process was the same. The idea was to make a revelation and to interact visually, intimately and, even, physically with the work. ${ }^{\text {IO }}$ It is therefore significant that some of the changes introduced into altar furnishing in the Crown of Aragon at that time saw folding doors or panels take centre stage, with movement being core to their raison d'être.

${ }^{8}$ On the other hand, the so-called 'Vírgenes-sagrario' are preserved in Mallorca, sculptures normally made of wood presenting a closed cavity with a door containing consecrated forms. See Llompart, I963, and Llompart, 2006.

9 'An image of the Virgin Mary with the story of figures and the image open'.

Io With regard to shrine Madonnas, Melissa Katz, claimed that these images have parallels with a range of containers of the holy which '[...] similarly enclose and disclose hallowed subject matter. A series of analogous objects, when compared to triptych Virgins, enhances our understanding of the theological and theoretical implications of a sculpted body of the Virgin fashioned with a set of doors. This in turn illuminates the dialectic established between the sculpture's exterior and interior, two spaces mediated by the gesture of opening and closing the image, a paraliturgical movement that approximates, for the person effecting the transformation, the passage between the mundane realm and the divine, crossing thresholds of augmented sanctity' (Katz, 20II, p. 70). 


\section{DOCUMENTATION AND TERMINOLOGY}

In contrast to what we mentioned earlier with regard to Valencia and Mallorca, exemplars have survived from Aragon and Catalonia, and there are documentary references explicitly mentioning the execution of tabernacle-altarpieces with movable wings. All the same, drawing on the sources, and with the exception of a contract from 1298 which we will be coming to later, the main problem we encounter is that certain documents that might refer to works of this type are not sufficiently explicit or descriptive. This is the case for a pastoral visit to Girona Cathedral in I4I7, where there is reference, with regard to the altar of the Holy Cross, which reads 'quedam postis fustea coram dicto altari posita et in qua sedet quedam imago virginis Marie lapidea' (Sureda, 2013, p. 44). It would appear that it is referring to something akin to a tabernacle-altarpiece, but the document just isn't specific enough.

To this we should also add the complex polysemy of the term 'tabernacle' in the Hispanic context, which comes into particularly sharp focus in Crown of Aragon documentary testimonies. It is as such that the word appears rather too rich in meanings that might allude to different sorts of altar furnishings (Español, 2002, p. I03; Español, 2009b, pp. 87-89). ${ }^{\text {II }}$ Be that as it may, on many occasions we encounter sparing and generic references to 'tabernacles', where it is not clear whether the works being alluded to had moving panels or not. On other occasions, the documents mention sculptures with their respective tabernacles, but we cannot tell if these were just images with a simple canopy above them, like a coronation, a more complex tabernacle-altarpiece with mobile wings, or a structure with a base and four columns supporting a canopy, but without folding wings.

${ }^{\text {II }}$ The term may also allude to different elements associated with the silver and goldsmithing world, such as the Eucharistic monstrances where the host was kept, or the niches presented by some processional crosses, as the documentation makes abundantly clear (Dalmases, 1992). The varying meanings of the term are rooted in a fairly clear and widespread basic semantic sparsity in the middles ages, with the assimilation of the Virgin as Christ's tabernacle. In other words, the Virgin as vessel. The Christ-centric literature produced under the Crown of Aragon allows us to reach this conclusion, with authors such as Romeu Llull or Sor Isabel de Villena (Torró, I992, p. 95, n. 7I).

${ }^{12}$ This type of furnishing bears parallels with the central part of a tabernacle-altarpiece, but few exemplars have survived other than the aforementioned Sant Martí d'Envalls one or the one from Sant Climent de Taüll, dating from the first half of the $13{ }^{\text {th }}$ century (Folch, 1925; Llarás, 1996). All the same, doubts have recently been raised as to whether the latter might not be the result of intervention subsequent to the date at which the image it contains was executed (Camps, 2008, p. I36). 
The above-mentioned polysemy, along with the inaccuracy of the descriptions provided in the documentation, are important handicaps when it comes to interpreting the nature of some of the many works mentioned in the major inventory drafted in Zaragoza in 1325 on the death of the painter and sculptor Ramón Torrent. Some were half-completed. An example of those that raise doubts would be, for instance, 'Una ymagen de Santa Maria, enjesada, de tres palmos, con su tabernaculo'; 'Un tabernaculo chico enjessado', ${ }^{14}$ or 'Dos ymagines de Santa Maria con sus tabernaculos, enjessadas, y la una començada d'argentar. ${ }^{\text {Is }}$ On another occasion there is mention of 'Una taula d'alçar [altar?], plegariça, enjessada $^{, 16}$ (Serrano Sanz, I9I8, pp. I08 and IIo). Torrent's widow, María Ximénez de Ribas, is an interesting figure who continued to run her deceased husband's workshop. As such, in 1327 she accepted a commission for Bartolomea Ximénez for 'dos ymagines, la una de Sant Bicent y la otra de Sant Martín, que ayan cada una dos palmos y dos dedos [...] con sus tabernáculos, y un otro tabernáculo que sia la historia de Sant Climent'. ${ }^{17}$ The dimensions (two hand spans and two fingers) and the price for the batch of images, 50 sueldos, relate no doubt to images intended for private worship, to the intimate piety of the home of the client. The one of most interest to us is the image of the story of Saint Clement, which could be interpreted as a tabernacle-altarpiece with movable wings, either painted or with sculptured relief work.

According to known models going back years, these elements with four columns and a canopy could take on greater dimensions, transforming into structures standing over the entire altar, with the mission of lending it dignity and protection. These are so-called ciboria, which, furthermore, sometimes crop up in the documentation as synonymous with 'tabernacle.. ${ }^{18}$ As such, we have re-

${ }^{13}$ 'An image of the Virgin Mary, in plaster, measuring three hand spans, with its tabernacle'.

I4 'A little plaster tabernacle'.

Is 'Two images of the Virgin Mary with their plaster tabernacles and one whose silver gilding has been started'.

${ }^{16}$ 'A folding, plaster altar [?] panel'.

${ }^{17}$ 'two images, one of Saint Vincent and the other of Saint Martin, each measuring two hand spans and two fingers [...] with their tabernacles, and another tabernacle depicting the story of Saint Clement'. See Serrano Sanz, I918, p. II5. The series of images had to be delivered 'daquia Pascua florida' (Easter Sunday), which shows that they had to be executed in the workshop and it was not a case of selling her dead husband's workshop stock.

${ }^{18}$ Regarding ciboria, see Kroesen, 20I4b, pp. 19-22. There are, however, cases, where the document mentions 'cimbori' and where it proves absolutely obvious that the reference is to what is known today as a ceiling baldachin (baldaquino-plafón, in Spanish). This is the case for a 1370 reference to a painter from Perpignan, Pere Baró, who was commissioned to paint a 'cobertz os cimbori 
corded proof that in 1398 the painter Gaucelm Paulet agreed to paint 'quoddam cimbori sive tabernacle' for the chapel of Corpus Christi at the church of Santa Maria del Pont in Perpignan (Gudiol Cunill, [n. d.], p. 173). ${ }^{19}$

Exactly the same is the case for the term 'altarpiece' (retablo, retaule), which on numerous occasions would be replaced by 'tabernacle' (tabernacle), especially during the second half of the $14^{\text {th }}$ century. ${ }^{20}$ By the descriptions provided in the documentation, we see these were altar furnishings normally presided over by a large tabernacle housing a sculpture, accompanied by painted side compartments. The great pre-eminence of the central element over the rest of the ensemble led on many occasions to it lending its name to said ensemble - a part standing for the whole. We observe this, for example, in a document from 1406 concerning dealings between Jaume Brot, a painter and sculptor, and the parish council of the Corpus Christi chapel of the church of Sant Jaume in Perpignan, who were involved in legal proceedings due to 'quoddam tabernaculum, et omnes picturas et ymaginem in ipso tabernáculo, factas et depictas [...]' (Madurell, 1949-52, I0, pp. 179-183, doc. 6I7).

Equally, some documents appear to show that the term 'tabernacle' might also refer to both little wooden triptychs with reliefs sculptured in ivory, and to

que es sobre l'artar de blau ab steles e ab la luna e solel' ('canopy or cimbori over the altar in blue with stars and the moon and sun') for the church of Santa Eugenia de Ortafa (Roussillon, France) (Gudiol Cunill, [n. d.], p. II6). It would appear that there is another reference to this sort of furnishing in the mention of a ciborium that existed at the high altar of the monastery of Sant Joan de les Abadesses (Girona). According to said monastery's necrology, it was paid for by the sacristan, Bernat de Castelló. Proceedings from 1458 reveal it had a dome with seraphs, held up by four columns sheltering the altar, which included images of Saint John the Baptist and Saint John the Evangelist (Parasols, I859, p. I4I).

${ }^{19}$ It may be that this identification between ciborium and tabernacle (as synonymous with altarpiece) was common in Northern Catalonia, given in 1308 Joan, a master painter from Perpignan, signed a contract with Dalmau de Fornells, chaplain of the parish church of San Juan y San Pablo de Sant Joan de les Abadesses, for the execution of three 'cimboris' for said church. One of these was for the high altar, dedicated to the patron saints of the temple, another for the altar of Saint Mary and another for that of Saint Gabriel. Each was to include three sculpted or inlaid images, two thurifer angels, one on each side of the 'sede majestatis'. These reliefs were to measure four hand spans high on the high altar ensemble, and three hand spans on the other two. The document also comments that silver leaf with mecca varnish (corladura) should be used where appropriate (Gudiol Cunill, I929, p. 36I).

${ }^{20}$ We see this in a contract from 1358 concerning the painter Jaume Serra, which mentions a 'tabernaculi sive reetaula' for the altar of San Miguel in Girona Cathedral (Madurell, I949-52, Io, pp. 28-30, doc. 404). In a document from two years later, the painter Francesc Serra, brother of the former, admits having received a sum of money from Romeu Ferrer, beneficiary of Barcelona Cathedral, in payment for a 'tabernaculi sive reetaule' (Madurell, I949-52, IO, pp. 39-40, doc. 416). 
those we find in a royal inventory from the period of Jaume II; ${ }^{21}$ triptychs or little altarpieces worked in metal, such as the one that existed in the personal chapel of King Pere III in $1344{ }^{22}$ or polyptychs with folding wings, such as the one Jaume II donated to Valencia Cathedral in $1319 .{ }^{23}$

Furthermore, when accompanied by the term 'retablo' (tabernacle-retables), the word has taken on a historiographic significance when it comes to designating a type of altar furnishing that was extremely characteristic of the Crown of Aragon (especially Catalonia), which has been studied by Francesca Español, where it is worth highlighting its use as a display cabinet for the Eucharist or holy relics. These were aniconic structures that embellished the altar without painted compartments, with varying levels and normally executed with lavish fretwork or gilt decoration. We know of pieces executed for the cathedrals of Barcelona, Mallorca, or Santa Maria de Manresa, among others (Español, 2009b; cfr. Pons/ Molina, 20I2, and Favà, 20I7, pp. I32-134). It would seem that we can trace the origin of these furnishings to the second half of the $14^{\text {th }}$ century, coinciding with a series of contemporary movements and changes that led to enriching the diversity of altar furnishings. Their historiographic labelling as 'tabernacle-retables' may give rise to confusion with the altar furnishings we are studying here, especially as the term for the latter is earlier, and well established, so perhaps

${ }^{21}$ The document is dated 1315 and relates to a series of gifts made by the monarch to individuals in his immediate surroundings. Of the works mentioned we find: 'unum tabernaculum de ligno cum imaginibus eburneis'; 'aliud tabernaculum ligni cum imaginibus eburneis', and 'item posuistis in altari sancti Nicholay, quod est in Palacio nostro Barchinone, aliud tabernaculum de ligno cum ymaginibus eburneis' (Martínez Ferrando, 1962, p. 99, doc. 68).

${ }_{22}$ The 1344 ordinances of the Royal Residence in Barcelona that said monarch ordered to be issued, speak of the need for his private chapel to include, among other things 'reretaula dargent daurat ab la imatge de la incorrupte verge Maria en lo mig loch daquel posada mostrantse dins tabernacle per tal que en les festes e en les altres covinents dies memoria d'ella no sia relaxada' (Gudiol Cunill, I929, p. 40I). In I354 we know that the same monarch had commissioned the goldsmith Pere Berneç to make a 'retrotabulum' dedicated to the Virgin 'cum tabernaculo argenteo esmaltato' (Gudiol Cunill, 1929, p. 399).

${ }^{23}$ 'Item altari predicto sancti Iacobi Sedis Valencie quasdam tabulas que clauduntur et intus est crucifixus cum cohopertis rubeis' (Martínez Ferrando, 1962, p. I44, doc. I05). It would seem that this is the same work that appears mentioned in an inventory of items from the Templar castle of Peñíscola (Castellón), from the same year: 'Item quasdam tabulas que clauduntur et intus est crucifixus cum cohopertis rubeis' (Martínez Ferrando, 1962, p. 146, doc. 106). A 1315 inventory commissioned by Jaume II includes a range of silver objects from the royal chambers which had to be cast in order to execute an image of the Virgin the king intended to offer to Monserrat monastery. These objects included a 'tabernaculum argenti cum imagine argenti beate Marie, ponderis viginti marcarum et duarum unciarum argenti' (Vilar, 2000, pp. I85-I86, doc. 68; this is also included in Sanjosé, 2017, p. I49, doc. 317). 
it would be appropriate to define the former as 'monstrance-retables' or 'monstrance-tabernacles'.

Finally, the term 'tabernacle' may refer to the type of cabinet used to hold the Eucharist. This is what we have come to know today as a Eucharistic tabernacle, which in the Crown of Aragon took on a range of formats in the medieval period. ${ }^{24}$ One such was the tower-shaped variety, which gave rise to free-standing works that could be placed above the altar (or towards the rear), and have folding doors. ${ }^{25}$ This is the case of the one preserved in the church of Codalet, in Northern Catalonia (Reynal, 2005, pp. IO2-I03; Favà, 2017, pp. I29-I30, figs 7-9). The introduction of this type of furnishing would appear to be a response, in Catalonia at least, to the varying ecclesiastical guidelines that started to be issued in the $13^{\text {th }}$ century, becoming consolidated in the second half of the $14^{\text {th }}$ century. As such, a synod ruling from the Vic bishopric in I348, speaks of 'Corpus Domini nostri Jesu Christi in aliquo armario juxta altare mundo et vicino ad id tantummodo diputato, sub clave devote et fideliter servetur' (Gudiol Cunill, I9I6, p. 72). Ten years later, Ramon de Bellera, bishop of Vic, banned the storage of the sacramental bread in the boxes normally used for keeping the silver, asking for it to be kept 'in aliquo eminenti et decenti loco juxta altare, adhibitis tamen clavibus' (Gudiol Cunill, I916, p. 72; Español, 2009b, p. 87). ${ }^{26}$ In 1372 Pere de Clasquerí, archbishop of Tarragona, ordered the jurats of Alforja to build a tabernacle behind the high altar which should be located under the main image, as existed in L'Aleixar. From that moment, and for the next few decades, we know of similar cases in a range of locations throughout said archbishopric, such as Albi, Belianes, Montbrió del Camp, Montagut, Conesa, Les Piles or Pon-

${ }^{24}$ Regarding the emergence of the Eucharistic tabernacle as an element of altar furnishing, its different types and the episcopal dispositions encouraging its popularisation, see Favà, 20I7, pp. I27-I34.

${ }_{25}$ Another well-known type of tabernacle, though less widespread in the Crown of Aragon, and also tower-shaped, might present its base on the ground and rise upwards, as is the case with the piece from the chapel of Mas Roig (Miramar, Mallorca) (Español, 2009b, p. 89, fig. 2).

${ }^{26}$ An earlier ruling by the archbishop of Tarragona set the tone, where in 1242 he requested 'in media parte altaris cum summa diligentia et honestate, sub clave si fiere potest, corpus domini custodiantur', although his request was clearly ignored in subsequent years (Español, 2009b, p. 87). These sorts of regulations were included in treatises that were disseminated internationally, such as the Rationale Divinorum Officiorum by Guillaume Durand, drafted in Italy prior to I286, including the stipulation for the altar to include a 'capsa in qua hostiae consecratae servantur'. Elsewhere in the same treatise he claimed that it should be arranged 'super altare' and, also that 'in quibusdam ecclesiis super altare collocatur arca seu tabernaculum' (Gudiol Cunill, I916, p. 69). 
tils (Capdevila, I925; Duran i Sanpere, 1932-34, vol. I, pp. I05-106). ${ }^{27}$ We also know of works commissioned from the sculptor Jordi de Déu for El Vilosell and Vinaixa (Beseran, 2009). Certain works showing this fervour have survived from the archbishopric, as can be seen in the undocumented free-standing stone tabernacle from El Vilet (Lleida) (Duran i Sanpere, 1932-34, vol. I, figs II8-II9). ${ }^{28}$

\section{TABERNACLE-ALTARPIECES AND ALTAR FURNISHINGS: A CONTEXT}

\section{OF TRANSFERRALS AND DEVIATIONS}

This phenomenon that was widespread throughout Tarragona coincided with the rise of the construction of stone altarpieces in the neighbouring area of Lleida, ${ }^{29}$ giving rise to a series of works that are grouped together under the title 'Lleida School of $14^{\text {th }}$-century sculpture', and which give an indication of the strides made in including the Eucharistic tabernacle within the altarpiece structure (Español, I995, p. 53 and II2)..$^{30}$ From its free-standing arrangement at the back of the altar, serving as a base for the sculpture standing over it, as we saw in the

${ }^{27}$ There are records of tabernacles fashioned in metal commissioned at a prior date for the monasteries of Sant Cugat del Vallès (Barcelona) (I3I4) and Poblet (Tarragona) (I332). See Español, 2009 b, p. 88 , n. 8.

${ }_{28}$ Also originating from a church in the Tarragona archbishopric, one surviving work is the one from Maldà (Lleida) (Museu Diocesà of Tarragona), although in this case it does not follow the free-standing tabernacle model, being a part of the altarpiece predella. See Duran i Sanpere, 1932-34, vol. I, fig. II8.

${ }^{29}$ As with our earlier comments regarding the archbishopric of Tarragona, we know of an episcopal ruling by the bishop of Lleida, Ramon de Ciscar (I238-I247), stipulating that in pulchriori parte altaris cum summa reverentia et diligentia et honestate, si fieri potest, Corpus Domini custodiatur' (Gudiol Cunill, I9I6, p. 70). A prior reference exists in the canonical corpus from the Lleida provincial in I229, which has clear echoes of the Fourth Lateran Council (Favà, 2017, p. 77).

${ }^{30}$ For more on the Lleida School, see Velasco/Yeguas, 20IO. One noteworthy example of Lleida stone altarpieces with an integrated Eucharistic tabernacle is found on the high altar of the church of Sant Llorenç de Lleida, or the one currently presiding over the church of Sant Miquel de Castelló de Farfanya (Lleida). The phenomenon may be extrapolated to stone altarpieces executed for other regions of Catalonia. This is the case of the Passion altarpiece originating from the monastery of Sant Joan de les Abadesses (Girona), undertaken by the sculptor Bernat Saulet in I34I (Museu Episcopal de Vic). Having undergone considerable transformation over the years, it has been suggested that it might have been one of the first examples where the Eucharistic tabernacle was included as a central part of the predella (Español, 2002, p. IO3). Something similar occurs with the silver altarpiece from Girona Cathedral, also affected by varying transformations, but which in around 1349-58, to coincide with its expansion, may have been fitted with a Eucharistic tabernacle (Español, 2005, pp. 22I-227). For more on the inclusion of such tabernacles in altarpieces, also see Favà, 20I7, pp. I30-I32. 
Vilet example, it started to be placed at the centre of the altarpiece, continuing to serve its purpose in supporting the main sculpture. These works are indicative of a model of receptacle without doors in the frontal area, but with a cavity to the rear allowing access. According to Kroesen (2009, p. 75), it was at this rear area that a sort of opening could be arranged, sculpted with angel or saint figures, and which could indeed be closed using a simple hinged wooden door, as is the case in Bellver de Cinca (Huesca) (Museu Nacional d'Art de Catalunya). ${ }^{3 \mathrm{I}}$

The series of retaules from the Lleida School are characterised by the monumentalisation of the altarpiece, with few precedents in contemporary Catalonia. In this context of the second half of the $14^{\text {th }}$ century, the incorporation of the Eucharistic tabernacle with folding doors towards the bottom of the altarpiece may have been part of a phenomenon whose core mission was to focus worshippers' attention on the furnishing presiding over the altar (Español, 2009b, p. 90). One might say much the same for the painted panel altarpieces which, among others, the Serra brothers did much to help popularise at the time. This is the sort of commission that would normally be associated with that of a tabernacle (and the documentation clearly bears this out) which would have to stand over it, and which provided shelter for the sculpture inside. ${ }^{32}$ When these ensembles took on greater dimensions they tended to be crowned by towering spires (agulles), which could stand more than Io metres tall, making it easier to capture worshippers' attention and focussing the spotlight on the church's main altarpiece. ${ }^{33} \mathrm{On}$

${ }^{31}$ The origin traditionally posited for this work was Albalat de Cinca (Huesca), but documentation come to light in recent years has demonstrated that its real origin was the neighbouring town of Bellver de Cinca (Berlabé, 2009, vol. I, p. II6 and I48-I50, II, pp. 4I8-426, III, pp. 330-366 and pp. 367-405, and Velasco/Yeguas, 20IO, pp. I86-187). According to Kroesen, there is a second work that might belong to the same model, although in this case not from the Lleida School. This is the frontal of the tabernacle from Vilafortuny (Tarragona), preserved today in the Museu Frederic Marès (Barcelona). Español, on the other hand, argues the possibility that these square-shaped framings might be used as the frontal of Eucharistic tabernacles sunk into the presbytery wall (Español, 2009b, p. 89, n. II).

${ }^{32}$ One might mention the case of the altarpiece commissioned from the painter Joan de Tarragona on 8 April 1359, who had to complete the miraculous image of the venerated Virgin for the sanctuary of Paretdelgada (Tarragona). The altarpiece was to be a triptych with the image in the middle, which the painter promised to take home in order to repaint it. The subjects of the paintings, two to each side, were to be the Annunciation, Nativity, Epiphany and Purification. He also undertook to paint a predella dedicated to the Passion. See Pié, I930 [I896], pp. 32-36. Two sections from the altarpiece are preserved in Tarragona's Museu Diocesà, which for many years were thought lost (Martí, 2008, pp. 22-25).

${ }^{33}$ This is the case of the lost altarpieces that presided over the churches of Santa Maria del Pi (Barcelona) and the monastery of Santa Maria in Pedralbes (Barcelona). In the case of the former, 
occasions, altarpiece and tabernacle were commissioned separately, as occurred when the brothers Francesc and Jaume Serra were, respectively, commissioned to undertake the painted compartments and main altarpiece for the monastery of Sant Pere de les Puel.les (Barcelona) in I360 (Madurell I949-52, IO, pp. 35-38, doc. $4 \mathrm{I} 2-4 \mathrm{I} 3) .^{34}$ These altar furnishings maintained major structural parallels with tabernacle-altarpieces, given apart from the leading role of the central tabernacle with its respective sculpture, they were surrounded by a number of side sections in vertical format that were symbolically equivalent to movable wings.

This volumetric and visual differentiation between the central element and the paintings surrounding it, characteristic of tabernacle-altarpieces, may be discerned from certain altarpiece contracts. Such is the case of one signed by the painters Jaume Serra and Bartomeu Bassa on I4 December 1358 with Ramon Sa Noguera and Guillem Vinyoles, residents of the town of Cardona. They agreed the polychromy of an image of Saint Michael as well as the execution of two altarpieces and a large tabernacle to house said sculpture (Madurell I949-52, IO, p. 32, doc. 406)..$^{35}$ According to the documents, the tabernacle was to measure three hand spans wide by 20 high, and should include two superimposed levels, a lower one for the image of Saint Michael, and an upper one to house the Eucharistic receptacle. The central tabernacle should be in between 'unum reetaula ab utrumque latus' (one altarpiece on each side), and it is as such that the commission speaks of 'two altarpieces'. The differentiation between the elements is quite

the height of the central tabernacle reached II metres, as can be concluded from the documentation (Ruiz, 2009, p. 290).

34 Separate commissions for the pictorial altarpiece and the tabernacle housing a sculpture were extremely common during the second half of the $14^{\text {th }}$ century. Among documented examples, we might also mention a couple of commissions associated with Llorenç Saragossa, a painter from Barcelona. On 9 December 1363 he signed a receipt for II and a half Barcelonese lliures in payment for an altarpiece painting and tabernacle he had undertaken to complete for the church of Castellnou de Bages (Barcelona) (Madurell, I949-52, 8, p. 24, doc. I2). Furthermore, on I8 March I370 he signed a payment receipt for carrying out 'cuiusdam tabernaculi et reetaule et su[i] scanni, sive banch' dedicated to Saint Eulalia for the high altar of the church of Santa Eulàlia in Provensana (L'Hospitalet de Llobregat) (Madurell, I949-52, 8, p. 33, doc. 24). This second document shows that, when commissioning an altarpiece, the term did not always refer to the entire ensemble, as a single furnishing, but that it was broken down into parts: central tabernacle, painted side compartments and predella, as in this case. Two years later, the Sallent parish council agreed on the execution of a tabernacle, an altarpiece and 'un rotllo d'esquelles', for whose completion they were still collecting alms in I388 (Solà, I920, p. 240; Sitges, 2003, p. 42).

35 Bernat Roca, mestre d'obra at Barcelona Cathedral at the time, was in charge of the carving and sculpting of the elements described (Madurell, I949-52, IO, pp. 30-31, doc. 405). 
clear, as we can see, given the whole ensemble was not conceived of as a single organic unit when it came to commissioning it. ${ }^{36}$

The lay-out of the large central tabernacle with scenes painted on both sides is what we can see in a work that has fortunately survived, the altarpiece presiding over the high altar of Tortosa Cathedral. Saying that, this impressive ensemble includes one innovative feature regarding what we have commented thus far; the movement of the side panels, something that makes it absolutely unique in the context of major surviving altarpieces in Catalonia, and which links it with central European altarpieces such as the one in Doberan (Germany) (Weniger, 200I, pp. 193-204). The Tortosa altarpiece must have been executed in around I35I ${ }^{37}$ at just the time that polyptychs were beginning to emerge in Catalonia. ${ }^{38}$ The Tortosa piece presents certain peculiarities that draw parallels with tabernacle-altarpieces, such as its horizontality, only broken up by the prominent and raised pinnacle at the top of the central tabernacle; its gabled tops, or the fact it presented scenes in bas-relief (with appliqué figures) on the inside of the wings and painted scenes on the outside. Liturgically, the movement allowed by the wings helped generate effects similar to those of tabernacle-altarpieces, beyond the scope of static altarpieces. We know that the Tortosa work remained closed for most of the liturgical calendar, but for major events or feast days it could be opened up. As such, worshippers were no longer restricted to seeing the outside painting, and

${ }^{36}$ We see something similar in the contract the abovementioned Bernat Roca signed three years later for the church of the convent of Mercè in Barcelona, when he was asked for 'Et eciam faciam ibidem unum rerataula [...] de tribus puntis, utriusque partis'. On this occasion, it was for a tabernacle measuring 54 hand spans high that was to house an image of Mary measuring seven hand spans. The painter Jaume Serra signed on this occasion as guarantor, along with the sculptor Pere Moragues (Madurell, I949-52, 8, pp. I7-20, doc. I0).

${ }_{37}$ On 23 August I35I, the Chapter of Tortosa Cathedral agreed on the building of a 'tabernaculum' dedicated to the Virgin Mary and intended for the high altar (Matamoros, 1932, pp. 137-I39). We therefore see that the same term was used as when referring to other types of completely different altar furnishings. For more on the Tortosa polyptych, see Conejo, 1997; Beseran, 1997; Alcoy/Buttà, 2005, pp. 22I-224.

${ }^{38}$ It is worth highlighting the Morgan polyptych, of a far smaller size ( 57 x $105 \mathrm{~cm}$ ), preserved today in the Pierpont Morgan Library in New York, attributed to the Bassas (Alcoy, 2005a, pp. I65-I68). Without a central tabernacle, it presents four panels with scenes from the lives of Christ and the Virgin Mary. It should be dated to a little before the Tortosa ensemble, and both its structure and the crown of its different sections could be compared to those of tabernacle-altarpieces. Another example of a contemporary polyptych is the one the Serra brothers executed for the monastery of Santa Maria in Pedralbes (Barcelona), preserved today, though broken up and scattered among different museums in Barcelona, Lille and Krakow (Español, 2002, p. 70; Alcoy, 2005b, pp. 268-269; Velasco, 20I9, pp. 82-85). It would have been completed shortly after the Tortosa altarpiece. 
could revel in the sculpted reliefs on the inside. The visual enhancement of the interior iconography thereby transformed into yet another means of expressing the solemnity of the occasion. This was the case, for instance, on the day that the keystone of the dome of the main apse was laid, in I438, according to one source: 'E vuy Diumenge quis compta XXVII de Setembre MCCCCXXXVIII lo dit retaule de la Seu sia ésser ubert e ben empaliat, sonen tots los senys e campanes, los quals ja la nit passada havien sonat' (Español, 2002, p. 190). ${ }^{39}$

Another example of a piece of altar furnishing with connections to the tabernacle-altarpiece is the one commissioned in 1337 from Guillem Ginebrer for the high altar of the church of Santa Coloma in Queralt (Tarragona) (Segura, I885, pp. 190-I9I; Español, 2002, pp. I88-I89; Fuguet, 2008). The document does not mention the word 'altarpiece' (retaule) at any point, using the term 'tabernacle' to refer to the ensemble. It also notes that the project should include a total of three tabernacles, and that the central one should be presided over by an image of the patron saint, Saint Columba, sculpted in stone, measuring eight hand spans. Two images of angels were to be installed in the auxiliary tabernacles, 'dezà e delä, or either side of the central one. The most interesting thing is that each one of these tabernacles opened up with two doors. The outside of the doors ('los caps de les portes') was to be adorned with carved decoration of a floral nature, while the inside was to depict three stories (istòries). The sum total then was six doors and I8 scenes, quite possibly of a Marian nature. As far as the execution technique of the scenes on these panels was concerned, the document notes that 'la obra dels camps de les istòries que sie obra plana' (the work on the fields of the stories should be flat)..$^{40}$ This probably meant bas-relief, appliqué sculptures, which would tie up with what we have seen regarding the Tortosa altarpiece and what was common in certain tabernacle-altarpieces, as we shall see when turning to the Santa Maria de Cap d'Aran ensemble. There is no doubt that the description provided by the documents presents us with an exceptional piece of Crown of Aragon altar furnishing, which shares internal structural features with

39 'And today, Sunday, 27 September MCCCCXXXVIII, may said cathedral altarpiece open and be decorated with tapestries, and may all the bells ring that rang out last night'.

40 '[...] e la obra del tabernacle que sie ab tres tabernacles, e en lo tabernacle miyà stigue la ymaya de santa Coloma e los àngels dezà e delà; et los tabernacles que s'obren ab VI portes, que axí és per son dret, e los caps de les portes que sien entaylades ab suplatges, e els fuylatges e les orles que tot sie embotit de bela obra d'entayl: sobre les portes, i dich en les portes, aye XVIII istòries, e la obra dels camps de les istòries que sie obra plana [...]'. See complete transcription in Manote/Terés, 2007 , p. 254. 
tabernacle-altarpieces. In fact, what we have here is a sort of integration of three tabernacle-altarpieces within one single more complex structure.

Another matter that needs to be addressed in this context of the transferrals and deviations we are tracing out here is the profound similarity to be found between the tabernacle-altarpieces with movable wings and certain primitive altarpieces that appear to bear a great resemblance to them. We are referring to a sort of altarpiece that was common in the first half of the $14^{\text {th }}$ century, which did not reach a great height, having a horizontal format with a central tabernacle and two or more side sections. This was a sort of transmutation of the tabernacle-altarpiece with movable wings into a two-dimensional static screen-altarpiece, while maintaining the same structure. We do not mean to claim that these primitive altarpieces were the consequence or next stage in the evolution of the tabernaclealtarpiece, but we are witness to works that owed a great debt to the Romanesque frontal structure which, quite simply, shared certain internal organisational features with the altar furnishing we are examining here. It is as such that, in spite of the flat and two-dimensional appearance, the structure of these primitive altarpieces was equivalent to that of a tabernacle-altarpiece with its wings unfolded. ${ }^{41}$ The vision provided to worshippers was similar, as both works were equally presided over by a main space in the form of a tabernacle, often crowned by an architectural canopy, with the full-length image of the Virgin or the patron saint. ${ }^{42}$ On both sides of this two-dimensional tabernacle there would normally be two or four auxiliary sections like fixed side wings with two (or more) levels of narrative scenes on top of each other. We see this in works such as the painted altarpiece from the monastery of Santa María de Casbas (Huesca), dedicated to Saint Ursula (Museu Nacional d'Art de Catalunya) (Gudiol Ricart, 197I, p. I75, cat. 53, fig. 86), the one that disappeared from the church of Vilobí d'Onyar in 1936 (Girona, circa I317), and originally from Girona Cathedral (Español, I992-93;

${ }^{4 I}$ These primitive altarpieces are mere transpositions of a frontal that would be arranged on top of the altar, as occurs with the Anglesola stone altarpiece (Lleida) (Museum of Fine Arts, Boston, US), or the Vallbona de les Monges ensemble of two painted panels, one of which served as a frontal and the other as an altarpiece (Español, 2002, p. I84). These two latter pieces present a format that is highly reminiscent of the Saint Peter frontal preserved in the Musée Art \& Histoire in Brussels (Melero, 1997).

${ }^{42}$ We can already identify two-dimensional central tabernacle features on certain late Romanesque altar frontals. We see this, for instance, in the frontals from the Ribagorza workshop originating from the Aragonese towns of Treserra (Museu de Lleida: diocesà i comarcal), Chía (Museu Nacional d'Art de Catalunya) and Rigatell (Museu Nacional d'Art de Catalunya), all being from the second half of the $13^{\text {th }}$ century. For more on these works, see Bertran, 2008. 
Español, 2002, p. I83), or the one preserved in the church of Marinyans, dated to I342 and preserved today in Serdinyà church (Conflent, France) (Freixas, 2005, p. III). One sculptural altarpiece worth mentioning is that of Saint Augustine preserved in the monastery of Sant Joan de les Abadesses (Girona) (Bracons, 2007, p. 149), where we observe that, on both sides of the central tabernacle, there are two side sections, at the narrower ends. These could be equated with the folding sections that tended to be used to close the central space at the front of the tabernacle-altarpiece. Finally, when it comes to works in metal, we find a number of altarpieces that present a similar structural arrangement, such as the one presiding over the presbytery of Girona Cathedral, completed in the mid-I4 ${ }^{\text {th }}$ century (Español, 2002, pp. 179-183).

The works mentioned are a sort of immobilised or static development on the tabernacle-altarpiece, as they stick to an extremely similar structure. For example, many of them have compartments with pointed or gabled tops, as seen in certain Castilian and European tabernacle-altarpieces. There are also parallels with the gablet-shaped canopy crowning the central tabernacle, as seen in two altarpieces from Mallorca attributed to Joan Loert, the Santa Quiteria one (Museu de Mallorca) and the Santa Eulalia one (Museu de la Catedral de Mallorca) (Llompart, I977-80, vol. 3, pp. 26-28, nos I5-16); and we even find identical decorative motifs with turreted shapes or fantastic beasts in the spandrels of said gablets, as seen in the stone altarpiece in the church of Santa Maria in Montblanc (Tarragona) (Liańo, 2007, pp. 133-135). In the two aforementioned pieces from Mallorca, we also observe that the saints in the main space are depicted on a polygonal pedestal base. With this element, the painter aimed to recreate a three-dimensional space reminiscent of a tabernacle presided over by a sculpture in tabernacle-altarpieces with movable wings. ${ }^{43}$

\section{TABERNACLE-ALTARPIECES WITH SCULPTURAL DECORATION ON THE WINGS}

On I September 1298, Master Nicolau, the sculptor, and three residents of the town of Santa Maria de Castelló de Empúries (Girona), the cleric Bartomeu de

${ }^{43}$ In fact, some period documents already bear witness to these transferrals between different artistic disciplines, as made clear by an inventory drafted in 1364 at Pedralbes monastery by order of Sister Sibila de Caixans, which mentions 'una taula [pintada] feta a manera de tabernacla, en que ha una ymage de madona sancta Maria' ('a [painted] panel done in the fashion of a tabernacle, including an image of Madonna the Virgin Mary') (Gudiol Cunill, 1902, p. 448). 
Puig, Jaume Ciricer and Berenguer Duran, signed a contract for the execution, within a period of one month, of a sculpture of Saint James measuring five hand spans high, and a tabernacle measuring seven spans high and between five and eight wide. The sculpture was to be polychromed in blue and white, while for the other parts of the work silver gilt should be used, along with a technique called 'embotit' (embossed plaster decorations with water gilding). The price agreed for the work was 200 sueldos (Pujol, 2004, pp. 196-197, doc. 3). What is most striking about the document is its comment that the tabernacle 'possit aperiri et claudi'; in other words, that it could be opened and closed with movable wings. It does not specify how said wings should be decorated, but it is important to bear in mind that the commission was granted to a sculptor, and that it was he who was charged with painting the central image and the tabernacle.

The first thing one notices in the document is something we have already mentioned; that there is no specific term to differentiate this type of furnishing. It is equally significant that the height of the tabernacle-altarpiece commissioned from Master Nicolau should match that of other examples of this type that have survived within a Hispanic context. The same cannot be said of the width, where the sculptor is asked to make the tabernacle between ' $\mathrm{V}$ et VIII palmos in amplitudinem', which is rather confusing. Perhaps we should interpret this to mean that the narrower wings, the outside ones closing the tabernacle at the front, should measure five hand spans, while the inside ones, which closed off the sides, should be wider. The chronology is also important, as the date takes us to the end of the $13^{\text {th }}$ century, just when the Linear Gothic language originating from France was taking hold in the Crown of Aragon, and as such we can conclude that the painting of the work's wings would have reflected those aesthetic parameters.

It says a lot that the commission should have gone to a sculptor who, judging by the document, not only took charge of the joinery, but also executed the sculpture's polychromy and the painting of the work. This is indicative of an issue that was commonplace in the Crown of Aragon in the $14^{\text {th }}$ century, with regard to the versatility of artisan-artists. It was therefore quite common to find artists appear in documentation as both sculptors and painters (Español, I997; Español, 20r6). ${ }^{44}$ Commissions such as the Castelló de Empúries one show that they had to be versatile and skilled in both artistic disciplines, to thereby undertake commissions such as the one we have just mentioned. We could enumerate

${ }^{44}$ Much the same was the case for Castile. For more on this, see Gutiérrez Baños, 2015, and Gutiérrez Baños, 2016. 
countless examples of this, ${ }^{45}$ but we will highlight just the one. Guillem Timor, who had settled in the Tarragona town of Montblanc, was recorded in January I345 as a painter commissioned to execute an alabaster sculpture of Saint Andrew for the parish of Selva del Camp (Tarragona) (Pié, I897, pp. I57-I58, doc. I). The document makes no mention of whether the image should be accompanied by a tabernacle. All the same, a little later, in February the next year, Timor accepted a commission for the execution of a series of painted panels to accompany the sculpture (Liaño, I991, p. 287, doc. 2). What we have there, then, is something of a mixed altarpiece, but we do not know how the central image and the painted compartments came together, or whether the latter were movable, like wings.

The versatility of these artists leads us to the case of a tabernacle-altarpiece that was discovered not long ago in the Val d'Aran in the Pyrenees. This is a partially-preserved work that presided over one of the altars in the church of Santa Maria de Cap d'Aran (Lleida) (Velasco/Ros/Gràcia, 2013-I4; Velasco/Ros, 2019) (Fig. I). Its side wings presented sculptured relief work which has sadly not survived. Executed in around 1300, its morphology and sculpture draw parallels with numerous known European exemplars, such as the Dädesjö tabernacle-altarpiece (Smäland, Sweden) (Tångeberg, 2009, p. 224, fig. I), or the one in Fröskogs church (Dalsland, Sweden), housed today in Stockholm's Statens Historika Museet (Lapaire, 1969, p. I77, fig. I2), to mention just two. Among Castilian pieces, we should mention the one from Castildelgado (Burgos), preserved today in the Museu Frederic Marès in Barcelona (inv. 8I4) (Frinta, 1967, p. I06, fig. 4; Lapaire, 1969, p. 175, fig. 9; Yarza, 1991, pp. 393-394; Gutiérrez Baños, 20I8, pp. 58-6o, fig. 4).

45 Without attempting to provide a complete list, we ought once again to mention Ramón Torrent, from Zaragoza, given both the documentation regarding his work, as well as the inventory drafted after his death in 1325 , mention images 'de bulto' ('with volume'), tabernacles and painted panels (Serrano Sanz, I918, pp. IO3-II3). Previously, in I260, the painter Bernat, his wife and Master Pere Martí de Burgos, with regard to a sculptural commission for a Descent from the Cross for the church of Santa Maria del Mar (Barcelona), promised not only to carve the wood, but also to polychrome it ('operabimus atque pingemus') (Gudiol Cunill, 1929, p. 453). In 1378 Bernat Pintor was living in Manresa, an expert in stone and wooden images, as those 'de pinzell' (done by brush) (Gudiol Cunill, [n. d.], p. I86), while in around I400, the assets inventory of the Perpignan painter Pere Baró, tells us that the artist worked as both a painter and a sculptor (Gudiol Cunill, [n. d.], p. II8). One of the paradigms of multi-skilled I4 ${ }^{\text {th- }}$ century Crown of Aragon artists is Guillem Seguer, who is recorded as an architect, a sculptor specialising in stonework, a master of stained glass windows and a painter (Español, 1994; Español 2007). We leave him to the end of our list because, as we shall see shortly, Seguer has been associated with what remains of a tabernacle-altarpiece housed today at the Museu Nacional d'Art de Catalunya. 
Although in Catalonia and Aragon other examples of tabernacle-altarpieces are still preserved that enable us to talk about this sort of liturgical furnishing taking root in the churches of said regions, none of these bears such close parallels as the Nordic ones. That may be due to the fact that in the first quarter of the $13^{\text {th }}$ century the area of the Pyrenees became an important hub for pictorial experimentation and for the production of liturgical furnishing, including ciboria or the so-called 'baldaquinos-plafón' (ceiling baldachins) (Castińeiras, 2008; Castiñeiras, 20II; Kroesen, 2013). With regard to the latter, workshops linked to La Seu d'Urgell, the episcopal seat, produced the oldest surviving ones in Europe, which may be explained by the dynamism of the region's artists and workshops. The output of these sorts of works in this area in around 1220-30 meant that, years later, the adjacent region of La Cerdanya became particularly receptive to the Linear Gothic innovations arriving from France, including such major works as the Soriguerola or Toses altarpieces (Melero, 2005). All this helped to mean that, in around 1300 , the northern part of the Urgell bishopric as well as the neighbouring French bishopric of Comminges, to which the Aran Valley belonged, became entry channels for types of liturgical furnishings not so well known in Catalan regions, such as the tabernacle-altarpiece.

Furthermore, it is important to emphasize that the tabernacle-altarpiece of Santa Maria de Cap d'Aran was presided over by a deacon saint carved in wood housed today at the Museu Nacional d'Art de Catalunya (inv. 3925) (Fig. 2). Research carried out as a consequence of the discovery of the remains of this tabernacle-altarpiece has demonstrated as much (Velasco/Ros/Gràcia, 2013-I4, pp. 156-159). This sculpture had been known of for a long time (it became part of the museum collection in 1932), and had been associated with an active sculpture workshop from the old bishopric of Comminges, possibly linked to the important religious hub formed around the cathedral of Saint-Bertrand (Batlle, 1965; pp. 509-510, fig. 2; Manote, 2007, pp. 45-46; Valle/Ros, 2018, pp. 35-38, fig. 2). The workshop's link to the episcopal seat was made based on the inscription found on the base of one of the sculptures making up the group, an image of a saint preserved in the Museu Nacional d'Art de Catalunya (inv. 64015), reading 'Hoc opus fuit factum apud sanctum Bertrandum Convenarum magistrum ubus [?] Doramaimus'. The inscription refers to where it was made, given the carving was from the church of Santa Eulàlia d'Unha, also in the Val d'Aran, along with a second saint belonging to the same workshop (inv. 64013) (Barrachina, 2013, pp. 20-2I). Other works surviving today confirm that the Comminges workshops worked for other parishes in the Aran region (Valle/Ros 2018). Meanwhile, it has been possible to calibrate the enormous repercussions their output had 
throughout the entire Comminges bishopric, of which the Aran Vale was a part in the early ${ }^{\text {th }}{ }^{\text {c }}$ century. As such, the widespread dissemination of these images is reflected in the large number of works it has been possible to identify in numerous museums and, in particular, churches from the area of the old diocese, not just in the Val d'Aran but also in the modern French départements of HauteGaronne and Hautes-Pyrénées (Velasco/Ros/Gràcia, 2013-I4, p. I52; Valle/Ros 2018). What we have here, then, is an extremely numerous group of sculptures produced by workshops that may have played a prominent role in introducing Gothic sculpture into Catalonia from France, between the $\mathrm{I}^{\text {th }}$ and $\mathrm{I} 4{ }^{\text {th }}$ centuries (Manote, 2007, pp. 45-46).

The fact that the Santa Maria de Cap d'Aran tabernacle-altarpiece was presided over by a sculpture from said stylistic environment led us at the time to wonder whether the piece of furnishing housing said image was also produced by these workshops. The answer is it was, given the polychrome decorative motifs found on the remains of the tabernacle-altarpiece are a perfect match for those on numerous works from the same workshop (Velasco/Ros/Gràcia, 2013-I4, pp. 152-I54). From all of the above we can conclude that the sculptural workshops in the Comminges area were not only given over to producing wooden carvings, but also examples of liturgical furnishings such as the one we are examining here. The obvious link between the Santa Maria de Cap d'Aran tabernacle-altarpiece and the Nordic and Castilian models also shows that said artisans were perfectly familiar with the nature and type of this altar furnishing, and one may suppose they specialised in their execution. Another aspect to be considered is that the advent of this sort of furnishing in the Catalonian region took place within the context of the stylistic Gallic influence characteristic of early Gothic sculpture. Numerous French sculptors settled in Catalonia during that period, so perhaps the arrival of these sorts of works should be considered in terms of innovations brought by artists. It is probable artists arriving from beyond the Pyrenees imported models of liturgical furnishing in the same way they also contributed specific visual artistic features. One might therefore almost speak in terms of a phenomenon of artistic colonialism specific to the reign of Jaume II (I29I-I327) and for which there is documentary evidence in other spheres, such as miniatures and goldsmithing, where we also observe the arrival of numerous foreign artists, many of whom were French (Español, 2002, pp. 76 et seq.; Español, 2009a).

The type of tabernacle-altarpiece we find in Santa Maria de Cap d'Aran belongs to a very specific type, with panels decorated in sculptural bas-relief (inlaid or carved directly onto the thickness of the wings), of which no others are 
known in the Crown of Aragon. It is clear that in areas such as Catalonia there was a certain tradition for executing similar works, as demonstrated by pieces such as the aforementioned Sant Martí d'Envalls ensemble and others from the Romanesque period, ${ }^{46}$ but we do not know to what degree the type represented by Santa Maria de Cap d'Aran and comparable works from Castile such as the one from Castildelgado were successful models of altar decoration. One similar example, although it presents contrasting visual features and structural aspects, may be seen in the remains of the tabernacle-altarpiece once located in the church of Sant Martí Sarroca (Barcelona) (Museu Nacional d'Art de Catalunya, inv. 15924-15925) (Fig. 3). All that survives are two panels depicting Our Lady of the Annunciation and one Magus from the Epiphany on the inside, while the outsides depict painted figures of Saint Peter and Saint Paul (Fig. 4). When the tabernacle was closed, these latter two acted as guardians and protectors of the Virgin inside, who disappeared during the Spanish Civil War and is only known by old photographs (Fig. 4 Camps i Sòria, in this volume). It is quite possible that we are missing two further panels with other depictions, one with the other two Magi and the other with the Angel of the Annunciation, according to the reconstruction proposal put forward by Folch i Torres (1956, p. 46, fig. XXI). The ensemble is of interest because it is a clear indication of sculpture's importance in this kind of piece, although now with far more prominent relief work than in Castilian and Nordic examples. From a chronological point of view, both panels have been dated to around I200 (Alcoy, I994; Camps, 2008, pp. 134-I35), although in our opinion they should probably be placed at a slightly later date, towards the end of the $13^{\text {th }}$ century, in the same context as the outside paintings, which may be clearly ascribed to the Linear Gothic. ${ }^{47}$ The presence of large-scale and full-length sculpted figures is reminiscent of European models, as we can see from a tabernacle-altarpiece originating from Vojňany (Slovakia) preserved today in the National Gallery of Bratislava (Frinta, 1967, p. I08, fig. 8; Cidlinská, 1989, p. 97).

Although they are slightly later works, much the same can be said for the four wings of the tabernacle-altarpiece housed at the Museu Nacional d'Art de Catalunya (inv. 9780-9783), dated to around 1335-45 (Favà, 2009, pp. 69 et seq.) (Fig. 5). In this case, each panel presents a scene painted in the upper section and inlaid high-relief figures in the lower section. As such, the gablet-shaped

${ }^{46}$ See the article by Jordi Camps in this volume.

${ }^{47}$ We suggested as such in Velasco/Ros/Gràcia, 2013-I4, p. I39. 
upper parts include painted depictions of the Visitation, Nativity, Annunciation to the Shepherds and the Presentation of Christ in the Temple, whereas in the lower parts we find sculpted figures representing the Epiphany (split across two wings), the Annunciation and a Saint Joseph. The mixed nature of the execution lends the work added interest, and forces us to ask whether the entire ensemble was carried out at the same workshop, as seen in the case of Santa Maria de Cap d'Aran. As such, the painting of the wings has been associated with the same painting workshop that completed the frontal and altarpiece from Vallbona de les Monges (Lleida) (Museu Nacional d'Art de Catalunya, inv. 9919 and 9920), along with the altarpiece of Saint John the Baptist and Saint Margaret originally from Alcover (Museu Diocesà of Tarragona, inv. 2970) (Favà, 2009, p. 7I). The grouping together of these works has interesting implications, given the aforementioned frontal and altarpiece had been attributed to Guillem Seguer (Español, 1994, pp. I8, 99 et seq.), a multi-talented artist living in Montblanc (Tarragona), who is recorded as being an architect, painter and sculptor. His versatility in wide-ranging artistic disciplines might justify his being the author of this tabernacle-altarpiece combining varying techniques. That would mean we are dealing with another multi-disciplinary artist as observed earlier when we referred to the sculptor Nicolau and his 298 tabernacle-altarpiece commission for Santa Maria de Castelló de Empúries, which also combined painting and sculpture.

\section{TABERNACLE-ALTARPIECES WITH PAINTED PANELS}

The painted scenes on these four tabernacle-altarpiece panels housed at the $\mathrm{Mu}$ seu Nacional d'Art de Catalunya serve to introduce a second and different type of piece to those we have seen thus far. We are referring to works completely lacking in sculpture on their wings, these being completely painted. The surviving ones we know of are all incomplete other than one, with only the wings having survived in the majority of cases. We should first mention one side wing from a tabernacle-altarpiece preserved at the church of Sant Andreu in València d'Àneu (Lleida), in the Pyrenees (Velasco, 20II, pp. 37-44) (Fig. 6). The existence of this work in the north of Catalonia reinforces the presence of this type of furnishing in the Pyrenean region, which is complemented by the case of Santa Maria de Cap d'Aran, and which we will be seeing again shortly when we deal with the panels from Santa Llúcia de Mur (Lleida). The panel from València d'Àneu (89.5 x $15.5 \mathrm{~cm}$ ) corresponds to one of the two that closed off the front of the ensem- 
ble's central tabernacle. This is confirmed by the fact that the wing is shaped like a quarter circle at the top. In terms of what is represented, we see three images of female saints in vertical-shaped compartments on top of each other. The figures stand out against a neutral-toned gilt background which is reminiscent of the one we can see in the backgrounds of the compartments of the Santa Maria de Cap d'Aran tabernacle-altarpiece. The spaces housing the figures are bordered by red polychromy from which a motif of six points surrounding a central one stands out. Of the three female saints we can only identify the lower one, Saint Catherine, remains of whose martyrdom attribute, spiked wheels, may still be made out, as well as the two executioners who lie vanquished at her feet. ${ }^{48}$ Just above the saint one can still identify a trace of the incised drawing of the angel about to break the wheels asunder with a sort of axe. The three saints look to the left, which no doubt indicates that in the second wing closing off the tabernacle the figures would be looking in the opposite direction in order to maintain symmetry. This arrangement matches what we observe on the back of the panel (Fig. 7), where we find the marks of two cross-pieces or hinges; a sloping one at the top and a second horizontal one towards the bottom. We also observe that the back was covered in a plaster-based preparation, undoubtedly decorated with blue or red polychromy to judge by the preserved remains. Reddish tones tend to appear on the back of the wings of tabernacle-altarpieces from Hispanic regions and other areas of Europe, as Andersen demonstrated in a recent study (Andersen, 20I5, pp. I72 and I8I-I82). At one time, the València d'Àneu panel was dated to the second half of the $13^{\text {th }}$ century due to its stylistic similarity with a range of works from the period (Velasco, 20II, pp. 42-43), although that date could certainly be pushed forward to the end of the century.

Also linked to the Linear Gothic, though somewhat later, are two panels from the Pyrenean church of Santa Llúcia de Mur (Lleida), which depict varying scenes from the hagiography of Saint Lucy (68.3 x 25.3 x I cm / 66 x 25.8 x 2 $\mathrm{cm}$, Museu Nacional d'Art de Catalunya, inv. 35073) (Fig. 8). This ensemble of works has a considerable historiographic background, ${ }^{49}$ although it is only today that they have been identified as wings forming part of a tabernacle-altarpiece. There are a number of elements backing up this theory, such as the hinge marks

$4^{8}$ The church in València d'Àneu belongs to the Urgell bishopric, whose cathedral (La Seu d'Urgell) was given over to the worship of the saint from the mid-I ${ }^{\text {th }}$ century on (Castiñeiras, 20IO).

49 See the bibliography included in Melero, 2005, pp. 80-83. Cfr. Buttà, 2005a, p. 71. 
on the edges, ${ }^{50}$ or the red polychromy on the back (Fig. 9), which link up with what we have just seen with the València d'Àneu exemplar. Apart from what we have mentioned, the vertical format, with one scene pictured above the other in each panel, and the arrangement of the narrative, also lead us to the same conclusion. With regard to said narrative, the sequence starts with the episode of the saint brought before Paschasius, Governor of Syracuse, while just underneath we see the attempt by two soldiers to drag the saint away with ropes. The story continues on the other wing with a rather odd martyrdom scene in which two executioners try to cut off her breasts, an episode taken from the hagiographic legend of Saint Agatha. ${ }^{\text {SI }}$ Underneath that, the cycle concludes with the saint's decapitation. Judging by the sequence, it seems fairly clear that this was part of a tabernacle-altarpiece presiding over the high altar of its church of origin, dedicated to Saint Lucy, and that the central element standing over it must have been a tabernacle with a sculpture of said patron saint. The surviving wings must have been those closing off the central aedicule at the two sides, whereas two smaller panels would have done the same at the front. This explains the hinge marks we mentioned visible on both edges of the panels, both the inner edge, which linked up to the central tabernacle, and the outer one, which was where they were joined to the smaller wings that have not survived. We do not know what scenes would have been depicted on the inside of these outer panels, but they may well not have been from the life of the patron saint, given the cycle on the surviving wings is fairly complete. Stylistically, Melero linked the panels to Barcelona workshops active in the execution of varying known mural ensembles, although she also detected parallels with the frontal from Santa Perpètua de Mogoda (Barcelona). She dated them to the second quarter of the $14^{\text {th }}$ century (Melero, 2005, p. 82), whereas Buttà preferred to date them as being from the late $13^{\text {th }}$ century or start of the following century (Buttà, 2005a, p. 7I).

Also housed in the Museu Nacional d'Art de Catalunya, and still to be published as being what they are, we find two wings from a tabernacle-altarpiece dedicated to the infancy of Christ (95.5 x $24.7 \mathrm{~cm} / 88.3 \times 24.3 \mathrm{~cm}$, inv. 35705) (Fig. Io). They were loaned to the museum by Ròmul Bosch i Catarineu and were subsequently (1950) donated to it by Julio Muñoz Ramonet when he acquired

so We are grateful for the physical inspection carried out by Núria Prat, conservator at the Museu Nacional d'Art de Catalunya, who confirmed the existence of the marks left by the hinges.

${ }^{5 I}$ As Melero already commented, we should take into account that St Lucy made a pilgrimage to the tomb of St Agatha along with her mother (Melero, 2005, p. 8I), which might explain the confusion. 
the Bosch collection. A 1979 photo preserved at the Institut Amatller d'Art Hispànic in Barcelona (ref. number E-3720) confirms that a third wing from the same ensemble existed in a private collection in Barcelona, ${ }^{52}$ with scenes from the Annunciation to the Shepherds and the Flight into Egypt (Fig. II). They had, to date, been identified as fragments of a hypothetical altarpiece (Gudiol-Alcolea, 1986, p. 35, cat. 59; Melero, 2005, pp. 19I-194), but it is obvious that they are the folding wings of a tabernacle-altarpiece. ${ }^{53}$ This appears to be borne out by their format with two scenes, one on top of the other, as well as the red polychromy we find on the back (Fig. I2), which we have become used to seeing in this sort of altar furnishing. A substantial margin on the upper part of the back seems to have been decorated in blue polychromy, along with another narrower strip towards the bottom. At the back we also observe clear marks of cross-pieces arranged at top and bottom, as was seen in the wing from Sant Andreu in València d'Àneu. All of the above leads us to conclude that these are two of an original four wings from a tabernacle-altarpiece dedicated to the Infancy of Christ, in all probability presided over by a sculpture of the Virgin with Child in the central tabernacle.

With regard to said ensemble's iconographic reading and scene arrangement, we would agree with Melero's suggestion, in spite of the fact that she thought of it in terms of a landscape-format altarpiece akin to the Marinyans one. ${ }^{54}$ She thereby posited a depiction of the Virgin with child in the central position. The iconographic narrative, from the viewer's left to right, would start with the Annunciation in the upper section of the wing that has not survived, continuing in the second (surviving) wing, with the Visitation, and would continue on the other side of the tabernacle with the third wing (also surviving), with the Nativity. The second wing on the right-hand side of the tabernacle-altarpiece would be the one preserved in a private collection, the upper section of which showed the Annunciation to the Shepherds. The reading would continue in the lower sections, meaning we have to go back to the outside wing of the left-hand side (not surviving), where we would find one of the Magi. This can be confirmed by the second wing, one of those preserved at the Museu Nacional d'Art de Catalunya,

52 The information associated with the photograph includes the measurements of said wing: $84.5 \times 22.5 \mathrm{~cm}$. The image confirms that it was trimmed slightly on the upper and right-hand edges.

According to Melero, in the museum's internal documentation the two wings preserved there are identified as 'movable panels, showing that the altarpiece ensemble of which they were part was made up of four folding wings accompanied by a central image of the Virgin' (Melero, 2005, p. I92).

${ }^{54}$ See the sketch published by said author (Melero, 2005, p. 192). 
the lower section of which depicts two of the Magi offering gifts in the central image, looking to the right (that is to say towards the central tabernacle). The cycle continues in the third wing with the Massacre of the Innocents and concludes in the outside wing on the right-hand side with the Flight into Egypt.

The origin of this ensemble is unknown, although the presence of gilt stucco relief led some to speculate that it may have been from Lleida (Gudiol-Alcolea, 1986, p. 35, cat. 59, fig. 157). Said decoration also appears in the four wings from the museum that we have already analysed, combining painting and sculpture (Fig. 5), and which were linked to the author of the frontal and altarpiece from Vallbona de les Monges. The fact that the name of Guillem Seguer has been put forward as the author of said works allows one to speculate on its origin in Lleida, as it is well-known that Seguer preferred to work in the areas of Tarragona and Lleida (Español, 1994). Be that as it may, in both cases the decorative motifs are extremely similar, based on a lattice made up of rhomboid shapes. Nor do the pictorial styles vary greatly from one ensemble to the other, although they were clearly by different painters. The Catalan origin of the wings we are dealing with here does, as such, seem quite clear. Gudiol and Alcolea dated both ensembles to the second quarter of the $4^{\text {th }}$ century (Gudiol-Alcolea, I986, p. 34). Melero, meanwhile, put them as being from the middle of the century (Melero, 2005, p. I93), whereas Favà dated the second works to the second third of the $14{ }^{\text {th }}$ century (Favà, 2009, p. 79).

One particularly significant and little-known tabernacle-altarpiece was in the Mateu collection in Barcelona in the first half of the $20^{\text {th }}$ century (Fig. 13). It was published by Manuel Trens in 1947, and it is known through a decent photo-reportage with numerous details preserved in the Institut Amatller d'Art Hispànic in Barcelona (ref. number G B-II23/B-II37). The information associated with said images catalogues the work as being $\mathrm{I}^{\text {th }}{ }^{-}$-century Italian. At the time of publication, Trens did not venture to say much about it, other than publishing the photo and commenting on the movable wings (Trens, 1947, pp. 684-685, fig. 398). It was unusual structurally in that it had a polygonal tabernacle in the shape of a half-hexagon whose three sides were crowned by quatrefoil roundels and gablets, which meant its format was unheard of in a Hispanic context. Said painted roundels included depictions of Christus Patiens (the middle one) (Fig. I4), and the Virgin and Saint John the Evangelist (to the sides). Furthermore, the tabernacle was supported on four free-standing helix-shaped columns with extremely prominent capitals, also reflecting a style unknown in the Iberian Peninsula.

In terms of the wings, the outer ones were narrower than the inner ones, and had painted decoration both on the inside and outside. All of the wings had a 
gablet at the top with a painted roundel in the middle. The two inner ones presented full roundels, both with angels depicted inside, while the outer ones, being narrower, had half roundels each with a symbol inside that we have not been able to identify. With regard to what is represented on the wings, here we find individual male and female saints, as well as the occasional hagiographic episode not part of any specific cycle. If we start our description with the inside (what was on show when the panels were open), on the wings closer to the central tabernacle we find the Baptism of Christ (Fig. 15), and the Mystic Marriage of Saint Catherine, Saint Martin cutting his cloak in two with the beggar, and the Stigmata of Saint Francis. As for the narrower wings, the upper section of the one at the far left has a friar in Franciscan habits with a three-knotted belt associated with the Order and holding a book. We must surely identify him as Anthony of Padua. In the lower section we find a female saint with a palm frond of martyrdom, crown and book. The fact that she appears just next to the scene depicting the Mystic Marriage of Catherine leads us to identify her with said saint. On the upper section of the outer wing of the opposite side we find Saint Louis of Toulouse, another of the Order's saints par excellence. In the lower section there is a female saint we have not been able to identify, dressed in Franciscan habit, the corded rope with three knots, a book and a rosary.

If we move on to the external decoration (what was visible when the wings were closed), the panel to the immediate right of the central tabernacle presents a full-length depiction of Saint Francis of Assisi with stigmata on his hands and side. He is also holding a book, from which we can read a fragment from Saint Paul's Letter to the Galatians, emphasizing the statement 'I bear the marks of Jesus on my body' (Galatians 6:17). With regard to the narrow wing on the righthand side, the old photos show that not much remained of the depiction of the figure from the upper section, although we will come back to that later. In the lower section we find another Franciscan saint, with habit and knotted corded rope, who is difficult to identify. If we move on to the other side of the tabernacle-altarpiece, the wing next to the central tabernacle shows a depiction of Saint Clare of Assisi that is in quite bad condition, although it is perfectly identifiable because the saint is seen bearing her crosier. Finally, the lower section of the wing to the far left presents a female saint whose identification is difficult due to the state of preservation and the lack of clarity of the images at our disposal. In the upper section meanwhile, we can clearly make out an angel, despite its poor condition when the photo was taken, because we can definitely identify the presence of a pair of wings. This figure is the pendant of the corresponding image in the upper section of the outer right-hand wing, of which very little remained 
as we mentioned earlier. Given that both complemented each other in discursive terms, we might suppose that the image that has all but disappeared was of the Virgin. The two images would thereby make up an Annunciation scene, quite suited to the front of a closed tabernacle-altarpiece.

The identification of the saints depicted on the inside and outside of the wings makes it quite clear that what we have here is an ensemble exalting the Franciscan Order, and as such we should not rule out it having originated from one of the Order's monasteries. It is harder to establish a geographic origin for the work given, as mentioned earlier, its type does not match any exemplars known in the Hispanic world. The polygonal structure and presence of roundels in the upper section of the inside of the wings is reminiscent of Italian works such as that of the Oratory of Mazzo di Valtellina, although that piece is from much later, the end of the $15^{\text {th }}$ century. ${ }^{55}$

The Italianate style of the painting of the ensemble being studied here is quite clear, reminiscent of Catalan paintings from the second half of the ${ }^{\text {th }} 4^{\text {century, }}$ such as those of the Serra brothers or the Master of Rubió. We see it, for instance, in the roundel at the top of the central tabernacle, where Christ (Fig. I4), Mary and Saint John the Evangelist are reminiscent of the same figures to be found in other works by the artists mentioned..$^{56}$ Equally, the Saint Louis of Toulouse is similar to the one presiding a panel from Barcelona Cathedral, today preserved in a private collection, which we attributed to Jaume Serra (Velasco, 2019, p. 56, fig. 27). ${ }^{57}$ Furthermore, the saint that we suggest identifying as Anthony of Padua, as well as the possible Saint Catherine, share general visible similarities with the Saint Olive and Saint Benedict from a panel originating from Santa Oliva (Tarragona) (Museu Diocesà de Barcelona) (Gudiol-Alcolea, 1986, p. 68, cat. I70, fig. 319). We are dealing with a painter of a profoundly Italianate style sharing a figurative culture similar to that of another master artist working in the Catalan region, the author of an altarpiece from Castelló de Farfanya (Lleida), preserved today in the Museu de Lleida, an ensemble transmitting a message with equally powerful Franciscan overtones (Gudiol-Alcolea, 1986, p. 66, cat. I60, fig. 305; Alcoy, I990, pp. 99-I00; Buttà, 2005b, pp. 31I-312; Nieddu, 2004-06).

"I I am grateful to Justin Kroesen who drew my attention to the existence of this parallel. See Lapaire, 1972, p. 53.

${ }^{56}$ See, for example, the central part of the Abella de la Conca altarpiece, a work by Jaume and Pere Serra (Velasco, 2019, p. I07, fig. 5I). Furthermore, this Christ is comparable to the one we find in the Museu Municipal de Moià (Barcelona), with similar forked beard and wrinkled brow (Velasco, 2019, p. I25, fig. 6I).

57 This panel had previously been attributed by Rosa Alcoy to Francesc Serra (Alcoy, 1993). 
The different depicted saints from the Order are highly reminiscent of those of our tabernacle-altarpiece, and one could say the same for the Stigmata of Saint Francis that appears at the top. It is important to bear in mind that the format and structure of the Castelló de Farfanya altarpiece are completely at odds with known works in Catalonia from the period and this, along with the markedly Italianate style of the painter, has led to suggestions that said artist may have been from Italy. That might also go for the tabernacle-altarpiece we are studying here. The punch marks on the saints' golden halos, however, seem more in line with local Catalonian tradition from the second half of the $4^{\text {th }}$ century, which could indicate a degree of cultural crossover in the painter. As such, the artist appears familiar with the Italianate style of the Bassas and pictorial features popularised by the Serra brothers, so it seems advisable to date the work to some unspecified point during the third quarter of the century.

In Aragonese regions, the few known tabernacle-altarpieces also seem to draw on the model of painted panels with no sculptural decoration. The first example has only partially survived, with just one wing remaining. It is preserved in the Museu de Terrassa (Barcelona) (IO6 x $24.5 \mathrm{~cm}$, inv. MT 37), and is dedicated to Saint Bartholomew (Fig. I6). ${ }^{58}$ The work was part of the Soler i Palet collection, and its exact origin is unknown. As with some of the pieces mentioned above, historiography had previously been unable to identify correctly the function and nature of the altar furnishing to which it belonged, with it having been considered part of a traditional altarpiece (Ruiz, I999, p. I9; Melero, 2005, pp. 162-I67). Saying that, and as recently commented by Favà (2019, p. I25), there is no doubt that it was part of a tabernacle-altarpiece, in terms of its morphology, the arrangement of scenes and, also, due to its presenting polychrome decoration on the back with rhomboid motifs similar to those seen in the Santa Maria de Cap d'Aran work, and to others we shall be turning to shortly in another Aragonese tabernacle-altarpiece, dedicated to Saint Nicholas. A reading of the inscriptions to be found in the margins separating one scene from another led Post to suggest the work as being of Aragonese origin (Post, 1930, vol. 2, p. 463), which was recently confirmed by Favà (2019, p. I25). Both the presence of informative inscriptions and the wing format are reminiscent of certain Castilian exemplars, such as the so-called 'Suma I altarpiece', preserved at Madrid's Museo Cerralbo, dedicated to Saint Clare and dated to around 1360-70 (Gutiérrez Baños, 2018,

${ }^{58}$ For an identification of the scenes and their iconography, see Post, I930, vol. 2, p. 463; Ruiz, I999, p. I9; Melero, 2005, pp. I62-167. 
pp. 68-74, fig. 8), or the 'Wildenstein altarpiece' housed at the Metropolitan Museum of Art from the late I $3^{\text {th }}$ century (Frinta, 1967, figs 9-13; Andersen, 2015, p. I80, fig. I5; Gutiérrez Baños, 2018, p. 68). Post dated our work to the late $13^{\text {th }}$ or early $14{ }^{\text {th }}$ centuries (Post, 1930, vol. 2, p. 463), although more recent suggestions place it as from a slightly later date, the second quarter of the $14^{\text {th }}$ century (Melero, 2005, p. 165).

The second of the known Aragonese tabernacle-altarpieces is preserved at the Museu Nacional d'Art de Catalunya (inv. 240oI) and is dedicated to Saint Nicholas the bishop of Myra (Fig. I7). It is of particular note because its central tabernacle has survived, with sculpture, supported on two columns with a castellated canopy, as well as the two wings that closed it off at the sides (Frinta, 1967, p. I06, fig. 7; Velasco/Ros/Gràcia, 2013-I4, pp. I4O-I42, fig. I4; Favà, 2019). It has, however, lost the two wings that closed it off at the front. The Aragonese origin of the ensemble has been supposed for some time (Frinta, 1967, p. I06), given the museum's internal records have it as originating from Huesca (Favà, 2019, p. I25). The four painted scenes from the life of the saint may be read from the top down, and from left to right, and the cycle would have continued on the lost wings. The work's identification is reinforced by the inscription that appears on the central frieze separating the upper and lower sections: 'istor/ia de/seino/r sa nic[olas]' (the story of lord St Nic[holas]) (Favà, 2019, p. I24). Decoratively, it is worth highlighting the rhomboid-shaped base decorating the panel behind the central sculpture, with a motif we find once again on the outside of one of the wings of the Santa Maria de Cap d'Aran tabernacle-altarpiece, and in the aforementioned Aragonese ensemble from the Museu de Terrassa, along with other European works such as the aforementioned one from Graubünden (Switzerland). The outside of the wings is painted red, which we have already seen in other works examined. Stylistically, both the central sculpture and the paintings indicate the second half of the $14{ }^{\text {th }}$ century (Favà, 2019, p. I25). Unfortunately, it has not been possible to identify the family to which the seven heraldic shields at the base of the central tabernacle belonged, all bearing the same coat of arms (gilt, four barry wavy fess azure).

The last Aragonese work we shall mention is, in fact, one of the most interesting for a number of reasons. Firstly, because until its disappearance in the Spanish Civil War it had survived intact. Secondly, because we know the name of the painter who painted it. And lastly, because we also know the names of the patrons who commissioned it and its date of execution. This combination of factors makes the ensemble a pretty exceptional example, within Europe, given it enables us to pinpoint its context of production. The work we are referring to is the 
tabernacle-altarpiece preserved until 1936 in the church of Belchite (Zaragoza) (Fig. I8). We can make up for its disappearance through a number of old photographs that give us a fairly accurate indication of its appearance.

The first thing we should note is that this piece of altar furnishing had not previously been identified with the tabernacle-altarpiece model we are studying here, given its cataloguing as a 'triptych' (Lacarra, 2004, pp. I7I-I73), or 'polyptych' (Gudiol Ricart, I97I, pp. 45 and 78, cat. 136). It is clear that it is neither one nor the other. The ensemble is structured around a main central tabernacle crowned by a canopy supported without columns at the front. This lack of support elements at the front is a structural simplification typical of later tabernaclealtarpieces, as Frinta commented (1967, p. I13)..$^{9}$ Nevertheless, we know several European works extremely similar to the Belchite ensemble, and from a similar period ( $15^{\text {th }}$ century), with also a gabled canopy, but which do have columns. This is the case for one piece from Tronsberg (Germany), housed today at the Bayerisches Nationalmuseum in Munich; for a second ensemble originating from Leiggern (Switzerland), today in the Schweizerisches Landesmuseum in Zurich (Frinta, 1967, p. IIo, figs I4-15); and for a third example from the Musée d'Art et d'Histoire in Fribourg (Switzerland) (Lapaire, 1969, p. 176, fig. II). This shows that later tabernacle-altarpiece models were widely circulated around Europe, as was the case for the older works we have been examining, and goes to explain the major similarities between the Belchite work and those from Germany and Switzerland.

Furthermore, the panel at the back of the central tabernacle from Belchite was decorated with round painted motifs executed using trimming, imitating contemporary silk fabrics. That space was originally presided over by a sculpture of the Virgin with Child, popularly known as the 'Virgen del Pueyo', as in 1725 it was moved to the neighbouring 'Del Pueyo' hermitage. This was an image dating from the second half of the $14^{\text {th }}$ century, measuring some $90 \mathrm{~cm}$ high and which survived the ravages of 1936 , but was sadly stolen in 1985. The tabernaclealtarpiece, however, remained in the parish church, although it was subsequently moved to the same hermitage. ${ }^{60}$ The four wings of the ensemble, each of a similar width, present scenes from the Joys of Mary in each of their two compartments.

59 This lack of columns is repeated, for example, in an exemplar from Friedberg (Germany), and in another from Västra Ed (Sweden) (Lapaire, I969, fig. I3), both from the $15^{\text {th }}$ century.

${ }^{60}$ It would seem that after the image and the furnishing were split up, the latter was occasionally taken to the church to be temporarily installed in the tabernacle-altarpiece and be worshipped by the locals. This information comes from Martín, 2009. 
The reading of the iconographic cycle started in the upper section of the wing on the far left, with the Annunciation. It continued with the second left-hand wing's upper image with the Visitation, and the reading continued underneath with the Nativity, thereby skipping the lower section of the wing on its left, where a kneeling donor is depicted dressed as a knight in arms. The sequence continued on the upper compartment of the inner right-hand wing with the Epiphany, carrying on with the upper compartment of the far-right wing with the Purification of the Virgin. The final scene, the Circumcision, appeared on the lower section of inner right-hand wing and to its right, on the final wing on that side, there is a second donor, kneeling once again and with a shield, helmet and military armour. The upper compartments are crowned with gablets decorated with flamboyant tracery, whereas the lower ones have semi-circular, poly-lobed arches on the inside. The outer wings were fitted with the typical triangular appendices which, when the ensemble was closed, secured the canopy at the front. It was to the side of said appendices that the heraldic symbols of the patrons depicted in the lower compartments were to be found, surrounded by starred decorations. In this case a rounded escutcheon, undoubtedly gilt, with a cross, gules, in the field. ${ }^{61}$

The first description we have of the ensemble comes from a local Belchite publication from I9OI, which reads: 'At the centre of this altarpiece there is a little canopy with Gothic gilt decoration, under which the Holy Image [of Our Lady of El Pueyo] was arranged, and two closing doors at the sides, the inside of which was painted with the mysteries of the life of the Holy Virgin and the portraits of the donors... devotees from Belchite to judge by the surname...' (Pintaned, I90I; cfr. Martín, 2009). The allusion to the surnames of the donors refers to an inscription at the back of the ensemble, reading: 'Este retaulo han fecho facer // los hondrados Pascual Bernat y Pedro Bernat // a onor e reverencya de Sancta Marya // anno de MCCCCXXXXVIIII'. ${ }^{62}$ It is significant that the word 'retaulo' give us an indication of the term being used for this sort of altar furnishing at that time. Furthermore, thanks to the text, we have a confirmed date for the execu-

${ }^{61}$ We know about the enamel on the cross thanks to the description in Tormo, 1909, p. 63.

${ }_{62}$ 'This altarpiece was commissioned // by the honourable Pascual Bernat and Pedro Bernat // in honour of and reverence for the Holy Virgin Mary // In the Year MCCCCXXXVIIII'. Transcribed in Bertaux, I9IO, p. 49; cfr. Tormo, I909, pp. 62-63. These publications appeared as a consequence of the Retrospective Exhibition held in Zaragoza in 1909, including a section dedicated to Gothic painting and featuring the work we are examining here. Only the tabernacle-altarpiece was taken to the show, and not the Del Pueyo Virgin, so that in the photos taken by Hauser y Menet to illustrate the texts by Bertaux and Monzó what we see presiding over the ensemble is a different sculpture, from the Mariano de Pano collection. 
tion of the work, I439, along with the names of those who paid for it, Pascual and Pedro Bernat, in all likelihood brothers. One would imagine they must have been members of an important Belchite family, given the sumptuous and noble attire with which they are depicted in the two compartments where they appear as donors, and taking into account that in 1449 there is a documented record of a local notary, Pedro Bernat, who could be identified as one of them (Cárcel, 2008, p. 178$)$. $^{63}$

The style of the paintings immerses the viewer in the International Style, and should be associated with the painter Blasco de Grañén (doc. I422-I459), previously known as the Master of Lanaja. ${ }^{64}$ This attribution dates the work to a fairly late period compared to the earliest examples of known tabernacle-altarpieces with movable wings in the Crown of Aragon, which first started to appear at the end of the $13^{\text {th }}$ century. The Belchite ensemble shows us that, almost 150 years later, this sort of altar furnishing was still being produced. In any case, the fact that we have been able to attribute the work to an artist such as Blasco de Grañén is of great significance, as that makes it one of the few European tabernacle-altarpieces for which we know all of the people involved, from its patrons to the painter who executed it. This is something that should be taken particularly into account given it is far more normal to be dealing with anonymous works that are difficult to associate with any specific patron. ${ }^{65}$ It is also important to highlight the fact that the presence of the heraldic emblems of the men who paid for the work, their depiction as donors, as well as the inclusion of an inscription referring to the commission on the outside of the wings, had a very specific goal; that

${ }^{63}$ We also have a 1390 record mentioning a 'Pedro Bernart' as a local resident (Contel, 1974-75, p. 38I).

${ }^{64}$ Post was able to see the work in person, although he never attributed it to the author of the Lanaja altarpiece (Zaragoza). He did however place it within the same context (Post, 1930, vol. 3, p. 2IO). It was Gudiol who came up with a definitive attribution for the Belchite tabernacle-altarpiece to the Master of Lanaja, also positing and arguing that the man behind said artistic figure was the painter Blasco de Grañén (Gudiol Ricart, 1955, p. 176; Gudiol Ricart, 1971, pp. 45 and 78, cat. 136). Final confirmation of this came when María del Carmen Lacarra identified a number of documents that certified that Blasco de Granén was the true identity of the aforementioned anonymous master (Lacarra, 1988). For more on the painter, see Lacarra's monograph on him (2004, passim), as well as subsequent contributions by Macías, 2013, vol. I, pp. 43-62, and Velasco, 2015.

${ }_{65}$ With regard to tabernacle-altarpieces that can be attributed to a specific named painter and with accurate dating, we could mention the Mazzo di Valtellina (Italy) work referred to earlier, which includes the signature of Giovanni Pietro Malacridis and a date of I489. See Lapaire, I972, p. 53 . 
of identifying the Belchite ensemble with those who had commissioned it, an aspect that reinforces the work's unique and exceptional nature.

\section{CONCLUSIONS AND FINAL QUESTIONS}

In this article we have attempted to illustrate how the phenomenon of the emergence of the tabernacle-altarpiece in the Crown of Aragon came about within the context of change and transformation affecting altar furnishing as the Romanesque gave way to the Gothic. Although during the Romanesque period we have found evidence of altar furnishing models structured around a central tabernacle, and some such ensembles might have even had side wings, as was the case with the Sant Martí d'Envalls aedicule, it would appear that the mobility of these wings was an aspect introduced at a later date, coinciding with the advent of the Gothic. Although the documentation is sparing in its illustrative references, and in spite of few exemplars having survived, what we know about triptychs, Eucharistic tabernacles and other similar works characterised primarily by this moving aspect would appear to support the above hypothesis.

It is harder, however, to resolve the issue of what motivations led specific patrons or customers to choose a tabernacle-altarpiece or polyptych over a traditional altarpiece. There is no doubt that the movement of their wings and the ritualistic possibilities of the opening and closing process were incentives, in certain contexts, for their being commissioned and executed rather than either frontals or traditional altarpieces. The theatricality of the act of opening and closing doors, the ability to reveal the image contained inside the central tabernacle, and then conceal it once more, was something not provided by the two-dimensional screens of frontals and traditional altarpieces. These movable elements acted like light switches, activating the sculpture presiding over the central tabernacle, and their inclusion in furnishings of this kind could be compared to what it meant to include Eucharistic tabernacles with doors as a central part of altarpiece predellas.

This needs to be understood within the framework of a phenomenon where movement takes hold of the altar in different ways, also including the proliferation of liturgical cabinets in specific parts of Catalonia, the occasional advent of altarpiece models with moving panels such as the one presiding over the Cathedral of Tortosa, or the execution of reliquary-cabinets with doors such as in the monastery of Piedra (Real Academia de la Historia). It is as such that, in the context of the Crown of Aragon, the tabernacle-altarpiece was part of a progressive 
process whereby altar furnishings became increasingly monumental, where altar frontals, free-standing Eucharistic tabernacles, ciboria and altarpieces interacted with each other. There were structural and morphological transferrals from one type to the other, and that explains the existence, for example, of altarpieces that look like altar frontals or, even, altarpieces where we cannot be sure that they weren't altar frontals. ${ }^{66}$ In any case, some of these works present aesthetic features, in terms of internal arrangement or structural configuration, reminiscent of the tabernacle-altarpieces with which they co-existed. This is something we have seen, for example, in the case of certain primitive altarpieces from Mallorca, such as the two painted by Joan Loert, which in spite of being made up of twodimensional horizontal screens, include a flat image in the central tabernacle on a polygonal pedestal base, which clearly evokes the third dimension of sculpture. Here we should also add the four side sections crowned by gablets we find in both works, which are also highly reminiscent of the four movable wings that open and close tabernacle-altarpieces.

The case of these two altarpieces from Mallorca leads us to raise the question of why there are no tabernacle-altarpieces in Mallorca or in Valencian regions. This could either be due to the twists of fate or simply because there never were any. Other questions that we might raise include the reason behind the leading role of the Pyrenees in the dissemination of this sort of altar furnishing, which might be a reflection of the fact that said region continued to be a hub for pictorial experimentation into the early $\mathrm{I}_{4}^{\text {th }}$ century, a legacy going back to the I3 ${ }^{\text {th }}$ century when the workshops around La Seu d'Urgell started making major contributions to the consolidation of certain types of altar furnishing, such as the ceiling baldachin. The adjoining region of Cerdanya also played a key role in the introduction of the Linear Gothic, so that the arrival of new artistic models from France may have come hand in hand with innovations including the introduction of types of tabernacle-altarpieces with close similarities to Nordic models. We see this in Santa Maria de Cap d'Aran, where we find an ensemble with appliqué sculptural relief on its wings almost identical to works to be found in lands as remote as Sweden, Germany or Switzerland. Those without sculpture on their wings were also similar to models that were widespread in the Europe of the day. We can identify close parallels between works that were divided by many miles and yet may even share in aspects such as red polychromy on the back of the panels, or rhomboid latticework decorating the front or back of the wings. These

${ }^{66}$ For more on this issue, see Bautista 2015. 
similarities enable us to establish direct comparisons between Catalan-Aragonese and Castilian exemplars, and between others from a wide range of European regions, within the framework of a coming together that is incredibly suggestive and full of nuances.

\section{BIBLIOGRAPHY}

Alcoy, R., 1990: Pintures del gòtic a Lleida, Lleida.

—, I993: "Els Serra dels inicis i la catedral de Barcelona. Aclariments entorn d'un retaule trescentista de Sant Lluís de Tolosa”, D’Art, I9, pp. I2I-I44.

_- 1994: "Edicle de Santa Maria de Sant Martí Sarroca”, in Catalunya Romànica, vol. I, Barcelona, pp. 308-310.

—_, 2003: "L'armari litúrgic de la catedral d'Elna i el seu mestre pintor. La formació, l'estil, els models i el catàleg", in M. Grau \& O. Poisson (eds), Elne, ville et territoire. L'historien et l'archéologue dans sa cité. Hommage à Roger Grau, Perpignan, pp. 287-304.

—_, 2005a: "Ferrer Bassa, un creador d'estil", in L'Art Gòtic a Catalunya. Pintura I. De l'inici a l'italianisme, Barcelona, pp. I46-170.

—, 2005b: "El taller dels Serra", in L'Art Gòtic a Catalunya. Pintura I. De l'inici a l'italianisme, Barcelona, pp. 254-272.

Alcoy, R. \& Buttà, L., 2005: "La pintura italianitzant a Tortosa”, in L’Art Gòtic a Catalunya. Pintura I. De l'inici a l'italianisme, Barcelona, pp. 22I-225.

Andersen, E., 2015: "Madonna Tabernacles in Scandinavia c. II5O-c. I350", Journal of the British Archaeological Association, 168/I, pp. 165-185.

Barrachina, J., I997: "Dues ales d'un edicle”, in Catalunya Romànica, vol. XXVI, Barcelona, pp. 354-355.

Barrachina, J., 2013: "Unes anotacions de procedències de la mà de Maties Muntadas", in B. Bassegoda \& I. Domènech (eds.), Antiquaris, experts, col-leccionistes i museus. El comerç, l'estudi i la salvaguarda de l'art a la Catalunya del segle XX, Bellaterra et alibi, pp. II-49.

Batlle, C., I965: "Un grupo de esculturas del Pirineo francés, en el Museo de Arte de Cataluña (Barcelona)", Anuario de Estudios Medievales, 2, pp. 509-510.

Bautista, I., 2015: Del frontal al retaule primitiu. Anàlisi cientifica de l'evolució tecnològica dels suports de fusta del gòtic lineal català, Ph.D. diss., Universitat de Barcelona.

Berlabé, C., 2009: El Museu Diocesà de Lleida. La seva formació i la legitimitat del seu patrimoni artistic, 3 vols, Ph. D. diss, Barcelona, Universitat Abat Oliba CEU. 
Bertaux, É., I9I0: Exposición retrospectiva de arte. I808-1908, Zaragoza.

Bertran, M., 2008: "L'anomenat taller de la Ribagorça: estat de la qüestió i nova aproximació", IBIX. Publicació biennal de cultura, arts, lletres, música i ciència dels dos vessants dels Pirineus, annals 2006-7, 5, pp. I83-196.

Beseran, P., 1997: "La dimensió italianitzant de l'estil de Moragues. Noves obres i nous arguments", Lambard. Estudis d'art medieval, ıо, pp. 99-I40.

—, 2009: "Jordi de Déu i el tabernacle del Vilosell", Talaia, 6, pp. 9-I2.

Bracons, J., 2007: "Bernat Saulet i el taller de Sant Joan de les Abadesses”, in L'Art Gòtic a Catalunya. Escultura I. La configuració de l'estil, Barcelona, pp. 139-154. Braun, J., I924: Der christliche Altar in seiner geschichtlichen Entwicklung, 2 vols, Munich.

Buttà, L., 2005a: "El Mestre de Santa Perpètua de la Mogoda i altres produccions catalanes", in L'Art Gòtic a Catalunya. Pintura I. De l'inici a l'italianisme, Barcelona, pp. 68-72.

—_, 2005b: "Els retaules de la conca del Segre", in L'Art Gòtic a Catalunya. Pintura I. De l'inici a l'italianisme, Barcelona, pp. 3II-3I4.

Camps, J., 2008: "Le mobilier d'autel en Catalogne à l'époque romane: devants d'autel et structures de retables sculptés", in Autour de l'autel roman catalan, Paris, pp. I25-I48.

Capdevila, S., 1925: "Custodies i sagraris", Lo Missatger del Sagrat Cor de Jesús, 409, pp. 32-38.

Cárcel, M., 2008: "Nombramientos de notarios públicos aragoneses (I4I9-I446)", Aragón en la Edad Media, 20, pp. 163-186.

Castiñeiras, M., 2008: "El baldaquí de Tost: una obra mestra de la pintura sobre taula", in El cel pintat. El baldaqui de Tost, Vic, pp. 3I-54.

_ , 20I0: "Santa Caterina retrobada: el programa de la catedral de la Seu d'Urgell i el seu context", in M. Castiñeiras \& J. Verdaguer (eds), La princesa sàvia. Les pintures de santa Caterina de la Seu d'Urgell, Barcelona, pp. 23-37.

__ 20II: "El altar románico y su mobiliario litúrgico: frontales, vigas y baldaquinos", in Mobiliario y ajuar litúrgico en las iglesias románicas, Aguilar de Campoo, pp. 9-75.

Cidlinská, L., 1989: Gotické krídlové oltáre na Slovensku, Bratislava.

Conejo, A., I997: "El retaule de la Verge de l'Estrella de Tortosa. Introducció dels corrents italianizants en la pintura de mitjan segle XIV a les terres de Tarragona", Lambard. Estudis d'art medieval, Io, pp. II-50.

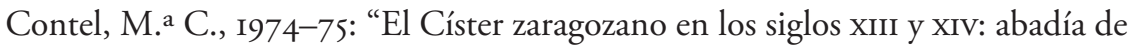
Nuestra Señora de Rueda de Ebro", Cuadernos de Historia Jerónimo Zurita, 27-28, pp. $195-465$. 
Dalmases, N. de, 1992: Orfebreria catalana medieval: Barcelona I300-I500 (aproximació a l'estudi), 2 vols, Barcelona.

Delcor, M., 1995: "Sant Martí d'Envalls”, in Catalunya Romànica, vol. VII, Barcelona, pp. 85-86.

Domenge, J., 2005: "Girona i el Rosselló a la segona meitat del trescents", in L'Art Gòtic a Catalunya. Pintura I. De l'inici a l'italianisme, Barcelona, pp. 305-3io.

Duran i Sanpere, A., 1932-34: El retaules de pedra, 2 vols, Barcelona.

Español, F., 1992-93: "El retaule gòtic de Vilobí d'Onyar, originari de la catedral de Girona", Annals de l'Institut d'Estudis Gironins, 32, pp. 35-44.

—, 1994: Guillem Seguer de Montblanc. Un mestre trescentista: escultor, pintor i arquitecte, Montblanc.

—., 1995: El escultor Bartomeu de Robio y Lleida. Eco de las plástica toscana en Catalunya, Lleida.

__, 1997: "La transmisión del conocimiento artístico en la Corona de Aragón (siglos XIV-Xv)", Cuadernos del CEMYR, 5, pp. 73-II4.

—, 2002: El gòtic català, Barcelona.

—_, 2005: "El escenario litúrgico de la catedral de Girona (s. XI-XIv)", Hortus Artium Medievalium, II, pp. 213-232.

—_, 2007: "Guillem Seguer de Montblanc", in L'Art Gòtic a Catalunya. Escultura I. La configuració de l'estil, Barcelona, pp. 154-165.

— - 2009a: "Artistas y obras entre la Corona de Aragón y el reino de Francia", in C. Cosmen, M. ${ }^{a}$ V. Herráez \& M. ${ }^{a}$ Pellón (eds), El intercambio artístico entre los reinos hispanos y las cortes europeas en la Baja Edad Media, León, pp. 253-294.

— 2009b: "Tabernacle-retables in the Kingdom of Aragón", in J. Kroesen \& V. Schmidt (eds), The Altar and Its Environment, II50-I400, Turnhout: Brepols, pp. 87-I08.

—_, 2016: "El artífice y sus habilidades. La transmisión del conocimiento artístico medieval" , in M. Miquel, O. Pérez \& M. Bueso (eds), Ver y crear. Obradores y mercados pictóricos en la España gótica (I350-I500), Madrid, pp. 97-I34.

Favà, C., 2009: "Noves consideracions entorn al joc de retaule i frontal de Vallbona de les Monges", Butlleti del Museu Nacional d'Art de Catalunya, Io, pp. 57-85.

- 2017: Imatge per a un culte emergent. Els retaules del Corpus Christi a la Catalunya dels segles XIV i XV, Ph.D. diss., Universitat Autònoma de Barcelona. 
—, 2019: "A tower for a universal bishop", in J. Kroesen, M. Leeflang, \& M. Sureda (eds), North \& South. Medieval Art from Norway and Catalonia II00-I350, Zwolle, pp. I23-I25.

Folch i Torres, J., 1925: "De com eren disposades les imatges escultòriques en l'altar romànic", Gaseta de les Arts, 2/2I, pp. 4-6.

—_, 1956: La pintura romànica sobre fusta (Monumenta Cataloniae, vol. IX), Barcelona.

Freixas, P., 2005: "Els obradors del nord-est de Catalunya", in L'Art Gòtic a Catalunya. Pintura I. De l'inici a l'italianisme, Barcelona, pp. IIo-II4.

Frinta, M. S., 1967: "The Closing Tabernacle: A Fanciful Innovation of Medieval Design", The Art Quarterly, 30, pp. I02-II7.

Fuguet, J., 2008: “Guillem Ginebrer i el retaule major de l'església de Santa Coloma de Queralt”, in J. Fuguet \& C. Plaza (eds), Història de la Conca de Barberà. Història de l'Art, Montblanc, p. 193.

Gaita, M. a del Mar, 1999: "Anònim. Retaulet de la Passió", in Mallorca gòtica, Barcelona and Palma, pp. I42-I44.

González Zymla, H., 2013: El altar relicario del monasterio de Piedra, Madrid.

Gudiol Cunill, J., I902: Nocions d'Arqueologia Sagrada Catalana, Vic.

—, 1916: "El Sagrario", Anuario Eclesiástico, 1916/Sección 3a , pp. 64-76.

- 1929: Els primitius. Segona Part. La pintura sobre fusta, Barcelona.

- - [n. d.]: Els trescentistes. El retrat. La pintura en taula. La pintura mural. La pintura en tela. La miniatura, Barcelona.

Gudiol Ricart, J., I955: Pintura gótica (Ars Hispaniae, vol. IX), Madrid.

- 1971: Pintura medieval en Aragón, Zaragoza.

Gutiérrez Baños, F., 20I5: "Una nota sobre escultura castellana del siglo XıII: Juan González, el pintor de las imágenes de Burgos, y el sepulcro de dońa Mayor Guillén de Guzmán en el convento de Santa Clara de Alcocer (Guadalajara)", Archivo Español de Arte, 88, pp. 37-52.

—_, 20I6: "La larga travesía del desierto: pintura y pintores en las fuentes castellanas de los siglos XIII y XIv', in M. Miquel, O. Pérez \& M. Bueso (eds), Ver y crear. Obradores y mercados pictóricos en la España gótica (I350-I500), Madrid, pp. 135-I70.

— 2018 : "Pasear entre ruinas: retablos-tabernáculo castellanos de la Baja Edad Media”, BSAA arte, 84, pp. 4I-83.

Katz, M., 20I0: Interior Motives: The 'Vierge ouvrante'/Triptych Virgin in Medieval and Early Modern Iberia, Ph. D. diss., Brown University.

—, 20II: "Marian Motion: Opening the Body of the Vierge Ouvrante", in N. Zchomelidse \& G. Freni (eds), Meaning in Motion. The Semantics of Movement in Medieval Art, Princeton, 20II, pp. 63-9I. 
Kessler, H. L., 20I4: "Paradigms of Movement in Medieval Art: Establishing Connections and Effecting Transition", Codex Aquilarensis, 29, pp. 29-48.

Kroesen, J., 2009: Staging the Liturgy. The Medieval Altarpiece in the Iberian Peninsula, Louvain/Paris/Walpole (MA).

_ 2013 : "Ciborios y baldaquinos en iglesias medievales. Un panorama europeo", Codex Aquilarensis, 29, pp. 189-222.

— 20I4a: "The Altar and Its Decorations in Medieval Churches. A Functionalist Approach", Medievalia. Revista d'Estudis Medievals, I7, pp. I53-I83.

— , 20I4b: "The Longue Durée of 'Romanesque' Altar Decorations. Frontals, Canopies, and Altar Sculptures”, in K. Kollandsrud \& N. Streeton (eds), Paint and Piety. Collected Essays on Medieval Painting and Polychrome Sculpture, London: Archetype, pp. 15-38.

Lacarra, M. ${ }^{a}$ del C., I988: "Cinco tablas del taller del pintor aragonés Blasco de Grañén (c. I422-I459) en el Museo de Bellas Artes de Bilbao", Urtekaria. Anuario del Museo de Bellas Artes de Bilbao, 1988, pp. 25-34.

- 2004: Blasco de Grañén, pintor de retablos (1422-I459), Zaragoza.

Lapaire, C., 1969: "Les retables à baldaquin gothiques", Zeitschrift für schweizerische Archäologie und Kunstgeschichte, 26, pp. 169-190.

__ I972: "Les retables à tabernacle polygonal de l'époque gothique", Zeitschrift für schweizerische Archäologie und Kunstgeschichte, 29, pp. 40-64.

Le Pogam, P.-Y., 2009: "L'Annonciation et la Visitation encadrant autrefois la Vierge en majesté tenant l'Enfant”, in P.-Y. Le Pogam, \& Ch. Vivet-Peclet (eds), Les premiers retables (XII -début du XV siècle). Une mise en scène du sacré, Paris, pp. 60-62.

Liaño, E., I99I: "Guillem Timor, un artista de Montblanc en el siglo XIv", in Homenatge a M. Antònia Ferrer i Bosch, Tarragona, pp. 273-293.

__, 2007: "Guillem Timor i l'escultura trescentista a Montblanc", in L'Art Gòtic a Catalunya. Escultura I. La configuració de l'estil, Barcelona, pp. 132-138.

Llarás, C., 1996: "Sant Climent de Taüll", in Catalunya Romànica, vol. XVI, Barcelona, p. 255 .

Llarás, C. \& Carabasa, L., I994: "Políptic", in Catalunya Romànica, vol. I, Barcelona, pp. 444-445.

Llompart, G., 1963: "Las Vírgenes-Sagrario de Mallorca", Bolleti de la Societat Arqueològica Lul.liana, 79, pp. I77-192.

_- 1977-80: La pintura medieval mallorquina. Su entorno cultural y su iconografia, 4 vols, Palma.

—_, 2006: "Les Marededéus sagraris de Mallorca", Miscel.lània Litúrgica Catalana, I4, pp. 6I-86. 
Macías, G., 2013: La pintura aragonesa de la segona meitat del segle XV relacionada amb l'escola catalana: dues vies creatives a examen, 2 vols, Ph.D. diss., Universitat de Barcelona.

Madurell i Marimon, J. M. a, 1949-52: "El pintor Lluís Borrassà. Su vida, su tiempo, sus seguidores y sus obras", Anales y Boletín de los Museos de Arte de Barcelona, 7, pp. 9-235, 8, pp. 9-387, I0, pp. 9-367.

Manote, M. ${ }^{a}$ R., 2007: "Els primers testimonis de l'assumpció de l'estil", in L'Art Gòtic a Catalunya. Escultura I. La configuració de l'estil, Barcelona, pp. 43-52. Manote, M. ${ }^{a}$ R. \& Terés, M. ${ }^{a}$ R., 2007: "Introducció", in L'Art Gòtic a Catalunya. Escultura I. La configuració de l'estil, Barcelona, pp. 246-255.

Martí, J., 2008: "Els misteris de l'Encarnació i de la Nativitat de Jesús en el retaule de Joan de Tarragona del Santuari de la Mare de Déu de Paret Delgada, a la Selva del Camp de Tarragona", Taüll, 22, pp. 22-25.

Martín, J., 2009: "El políptico de Belchite (año I439)", in Belchite: imágenes, notas históricas y evocaciones. URL: http://belchitelaureado.blogspot.com/2009/07/ el-poliptico-de-belchite-ano-I439.html?m=I (accessed 23 November 2019).

Martínez Ferrando, J. E., I962: "La Cámara Real en el reinado de Jaime II (I29I1327). Relaciones de entradas y salidas de objetos artísticos", Anales y Boletín de los Museos de Arte de Barcelona, II, pp. I-230.

Matamoros, J., 1932: La catedral de Tortosa, Tortosa.

Melero, M., 1997: "La tabla de san Pedro del Museo Real de Bruselas. Nuevas aportaciones al estudio de la pintura del gótico lineal catalano-aragonés”, Locus Amoenus, 3, pp. 25-38.

- 2005: La pintura sobre tabla del gótico lineal: frontales, laterales de altar y retablos en el reino de Mallorca y los condados catalanes, Bellaterra et alibi.

Nieddu, L., 2004-06: "El retablo de Castelló de Farfanya en el marco de la pintura toscana del siglo XIv", Seu Vella. Anuari d'Història i Cultura, 5, pp. 329-335.

Parasols, P., I859: San Juan de las Abadesas y su mayor gloria al Santísimo Misterio, Vic.

Pié, J., I897: "Documentos inéditos del archivo parroquial de la Selva del Camp. Contrato del escultor Guillermo Timor de Montblanc", Revista de la Asociación Artístico-Arqueológica Barcelonesa, 2, pp. 157-159.

—, I930 [1896]: Relación histórica del Santuario de Paret Delgada, Reus.

Pintaned, J., I90I: Apuntes históricos de Nuestra Señora del Pueyo de Belchite, Zaragoza.

Pons, A. \& Molina, F., 20I2: "Reformas y pervivencias medievales en la Capilla Real de la Seu de Mallorca. El caso del retablo gótico del altar mayor (s. xvxx), Porticum. Revista d'Estudis Medievals, 3, pp. 72-100. 
Post, Ch. R., 1930: A History of Spanish Painting, vols. I-3, Cambridge (MA). Pujol, M., 2004: Pintors $i$ retaules dels segles XIV $i$ XV a l'Empordà, Girona.

Reynal, J., 2015: L'art gothique en pays catalan: sur les pas des rois de Mallorca, Toulouse.

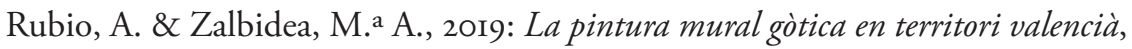
Benicarló.

Ruiz, F., 1999: "A l'entorn de les pintures gòtiques del Museu de Terrassa", in Art Medieval. Una col.lecció del Museu, Terrassa, pp. 19-29.

—_, 2009: "L'evolució del retaule", in L'Art Gòtic a Catalunya. Sintesi general. Indexs generals, Barcelona, pp. 288-298.

Sanjosé, L., 20I7: Esments d'orfebreria litúrgica en la documentació catalana (segles IX-XIV). Recull provisional, Vic.

Segura, J., I885: "Aplech de documents curiosos e inèdits fahents per la història de las costums de Catalunya", in Jochs florals de Barcelona, Barcelona, pp. II9-287.

Serrano Sanz, M., 1918: "Documentos relativos a la pintura en Aragón durante los siglos XIV y Xv", Revista de Archivos, Bibliotecas y Museos, 36, pp. I03-II6.

Sitges, X., 2003: "Els tabernacles gòtics bagencs", Dovella, 79, pp. 40-42.

Solà, F., I920: Historia de Sallent, Vic.

Sureda, M., 20I2: "La imagen en el altar. Reflexiones sobre localización, propiedades y utilidades de la imagen esculpida a partir de ejemplos catalanes del medioevo", Codex Aquilarensis, 28, pp. 75-94.

__ 2013: "Les lieux de la Vierge, notes de topo-liturgie mariale en Catalogne (xie-Xve siècles)", in M.-P. Subes \& J.-B. Mathon (eds), Vierges à l'Enfant médiévales de Catalogne. Mises en perspectives, Perpignan, pp. 39-70.

Tångeberg, P., 2009: "Retables and Winged Altarpieces from the Fourteenth Century: Swedish Altar Decorations in Their European Context", in J. Kroesen $\&$ V. Schmidt (eds), The Altar and Its Environment, IISO-I400, Turnhout, pp. 223-240.

Tormo, E., 1909: "La pintura aragonesa cuatrocentista y la retrospectiva de la exposición de Zaragoza en general", Boletin de la Sociedad Española de Excursiones, 17 , pp. 57-75.

Torró, J., I992: "Romeu Llull i la poesia de certamen: els Vint triomfs", Caplletra. Revista Internacional de Filologia, I3, pp. 85-98.

Trens, M., 1947: María. Iconografía de la Virgen en el arte español, Madrid.

Valle, C. del \& Ros, E., 20I8: "Es escultures deth grop de Comenge ena Val d'Aran", in Aran Me Fecit. Des mèstres constructors ara recèrca deth patrimòni sacre, Vielha, pp. 35-38. 
Velasco, A., 20II: Devocions pintades. Retaules de les Valls d'Àneu (segles XV i XVI), Lleida.

—_, 2015: "Novetats del mercat d'art en relació amb la pintura gòtica aragonesa: Blasco de Grañén (doc. I422-I459)", in Viatges a la bellesa. Miscel.lània homenatge a Maria Rosa Manote i Clivilles, Barcelona, pp. I6I-I7I. URL: http://www.ruizquesada.com/index.php/es/retrotabulum-mayor-esp/I83retrotabulum-mayor-nI-viatges-a-la-bellesa-miscellania-homenatge-a-mariarosa-manote-i-clivilles (accessed I September 2019).

—, 2019: Saint Martin and the Beggar. A Masterpiece by Jaume and Pere Serra, Buenos Aires.

Velasco, A. \& Ros, E., 2019: "A tabernacle shrine in the Aran Valley", in J. Kroesen, M. Leeflang, \& M. Sureda (eds), North \& South. Medieval Art from Norway and Catalonia II00-I350, Zwolle, pp. 173-175

Velasco, A., Ros, E. \& Gràcia, M. ${ }^{a}$ J., 20I3-I4: "Un retaule-tabernacle gòtic a Santa Maria de Cap d'Aran (Tredòs, Val d'Aran)", Lambard. Estudis d'art medieval, 25, pp. I19-168.

Velasco, A. \& Yeguas, J., 20Io: "Noves aportacions sobre l'Escola de Lleida d'escultura del segle xIV", Urtx. Revista Cultural de l'Urgell, 24, pp. 175-206.

Vilar, M. ${ }^{a}$, 2000: Els béns del Temple a la Corona d'Aragó en suprimir-se l'orde (I300-I319), Barcelona.

Weniger, M., 200I: "Doberan, Cismar - Tortosa”, in H. Krohm, K. Krüger \& M. Weniger (eds), Entstehung und Frühgeschichte des Flügelaltarschreins, Wiesbaden: Reichert, pp. 193-204.

Yarza, J., I99I: "384.- Tabernacle", in Catàleg d'escultura i pintura medievals (= catalogue Museu Frederic Marès), Barcelona, pp. 393-394.

Zchomelidse, N. \& Freni, G. (eds), 20Ir: Meaning in Motion. The Semantics of Movement in Medieval Art, Princeton. 


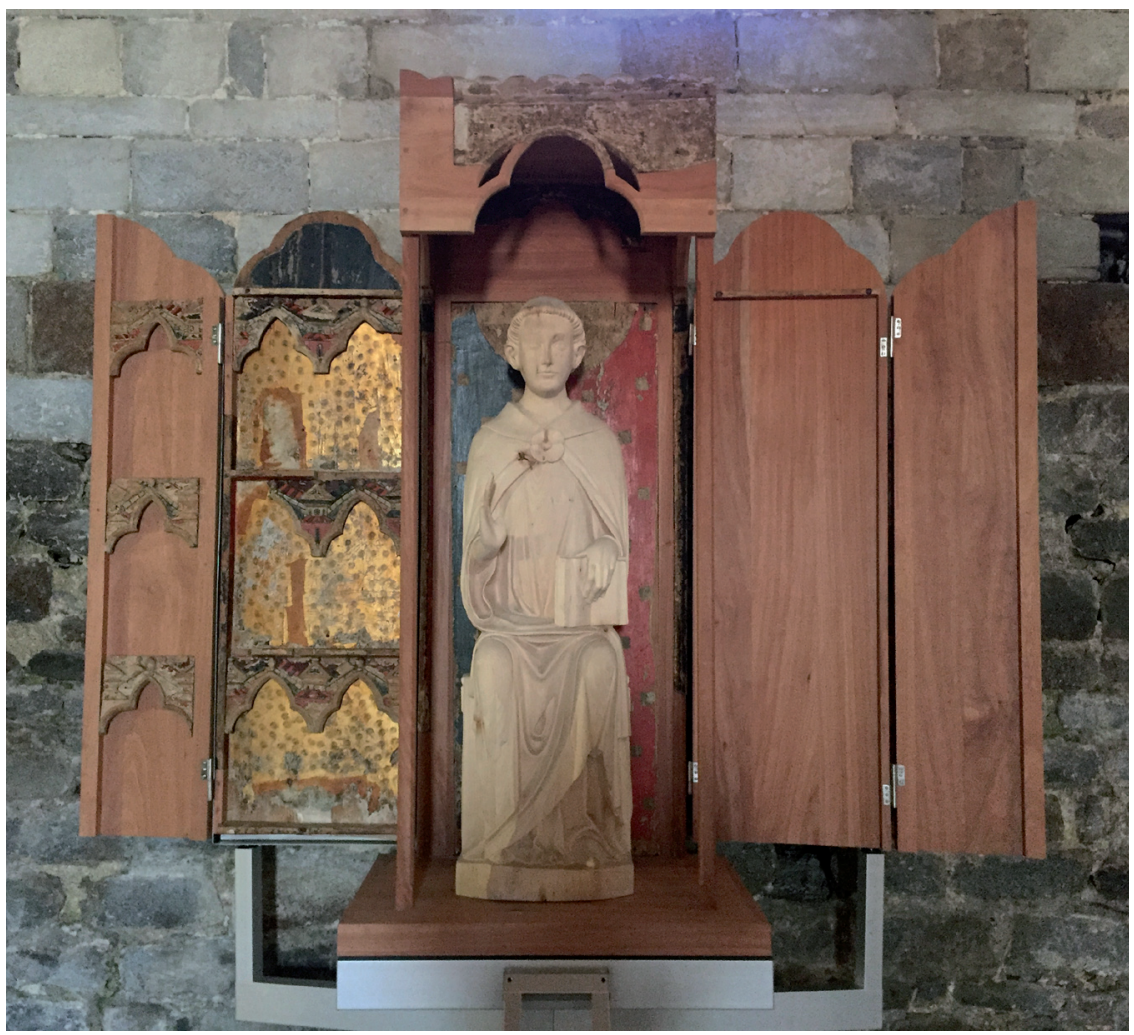

Fig. I. Tabernacle-altarpiece preserved in Santa Maria de Cap d'Aran, Lleida. Photo: A. Velasco. 


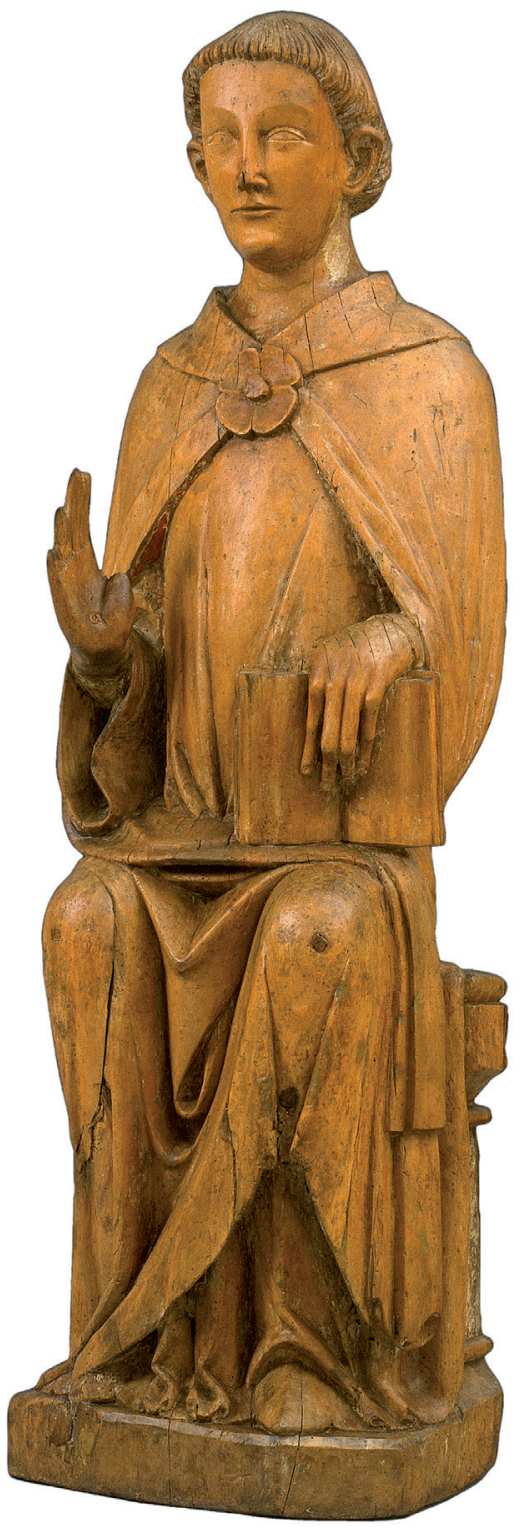

Fig. 2. Deacon Saint originating from Santa Maria de Cap d'Aran, Museu Nacional d'Art de Catalunya, Barcelona.

Photo: Museu Nacional d'Art de Catalunya, Barcelona (2020). 

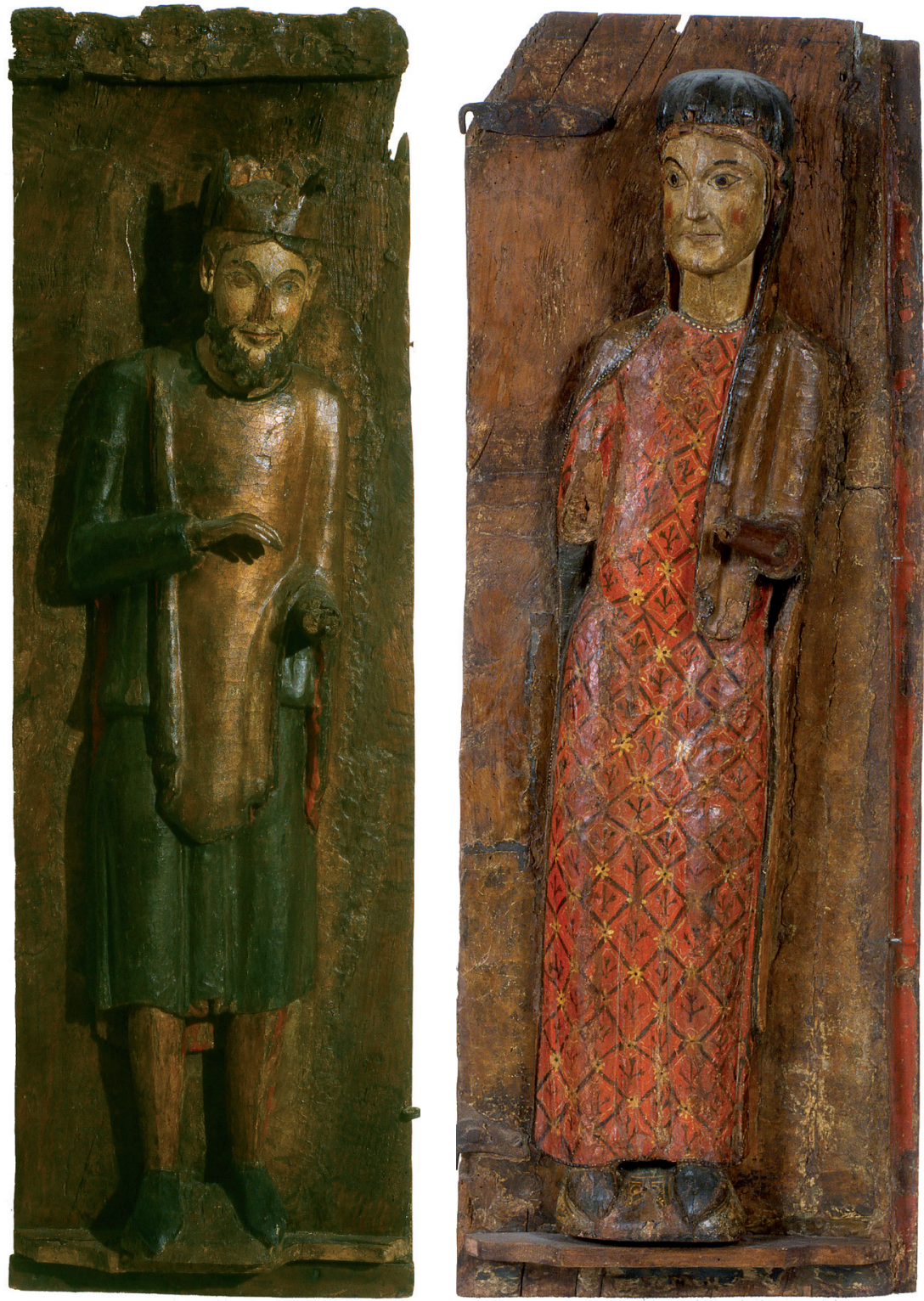

Fig. 3. Inside of two tabernacle-altarpiece panels originating from Sant Martí Sarroca, Museu Nacional d'Art de Catalunya, Barcelona.

Photo: Museu Nacional d'Art de Catalunya, Barcelona (2020). 

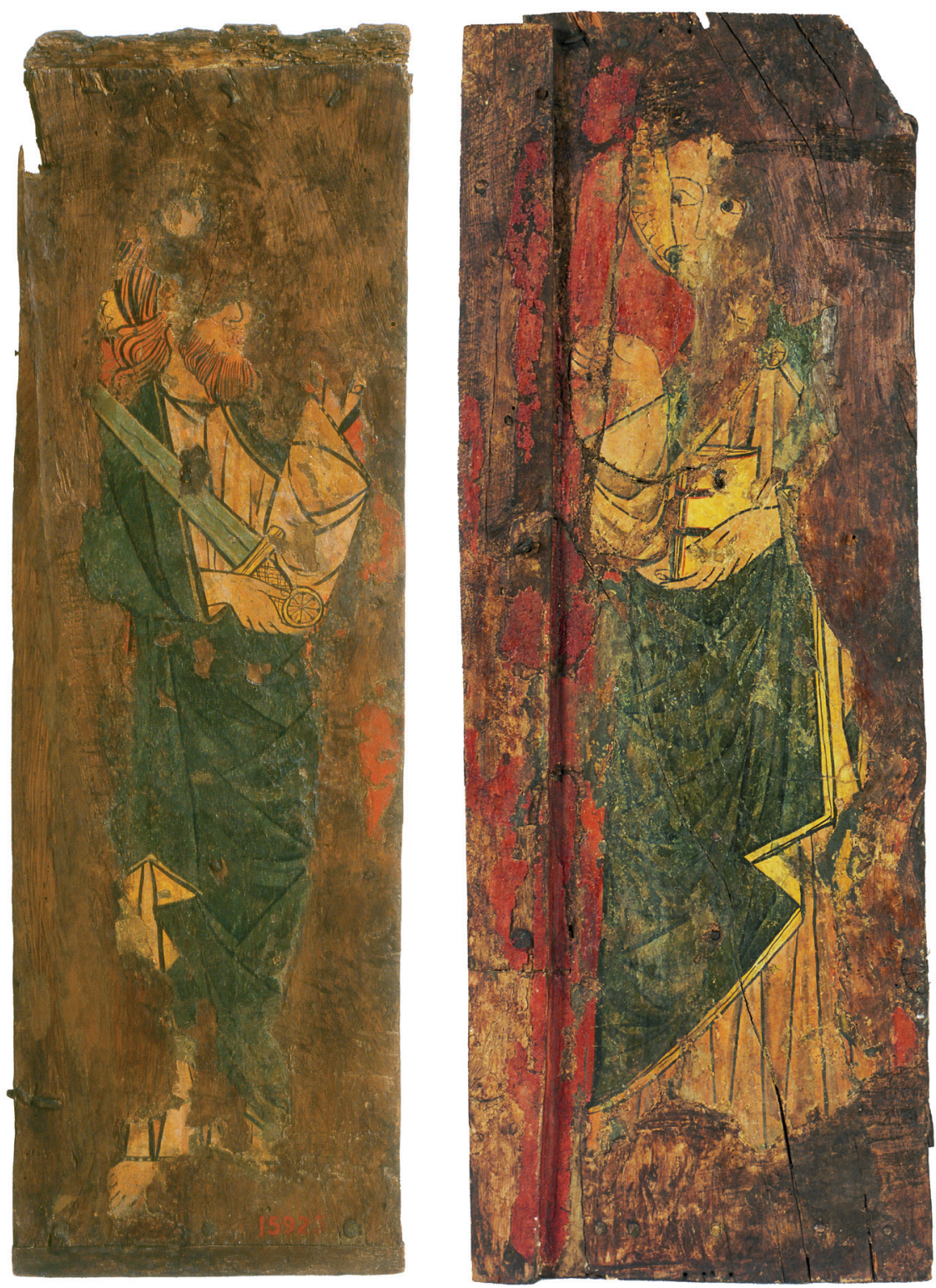

Fig. 4. Outside of two tabernacle-altarpiece panels originating from Sant Martí Sarroca, Museu Nacional d'Art de Catalunya, Barcelona.

Photo: Museu Nacional d'Art de Catalunya, Barcelona (2020). 


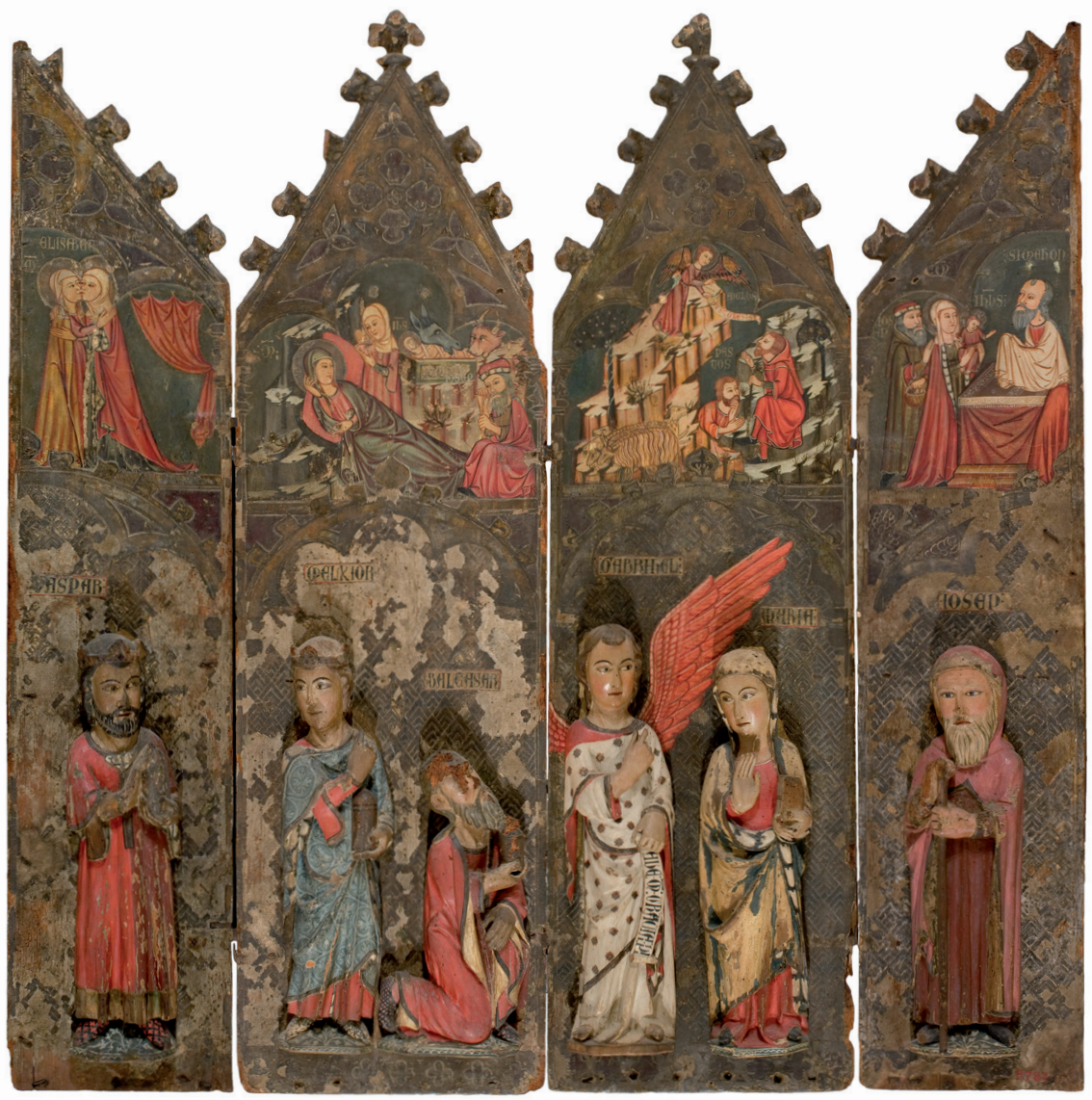

Fig. 5. Guillem Seguer (?), panels from a tabernacle-altarpiece, Museu Nacional d'Art de Catalunya, Barcelona.

Photo: Museu Nacional d'Art de Catalunya, Barcelona (2020). 


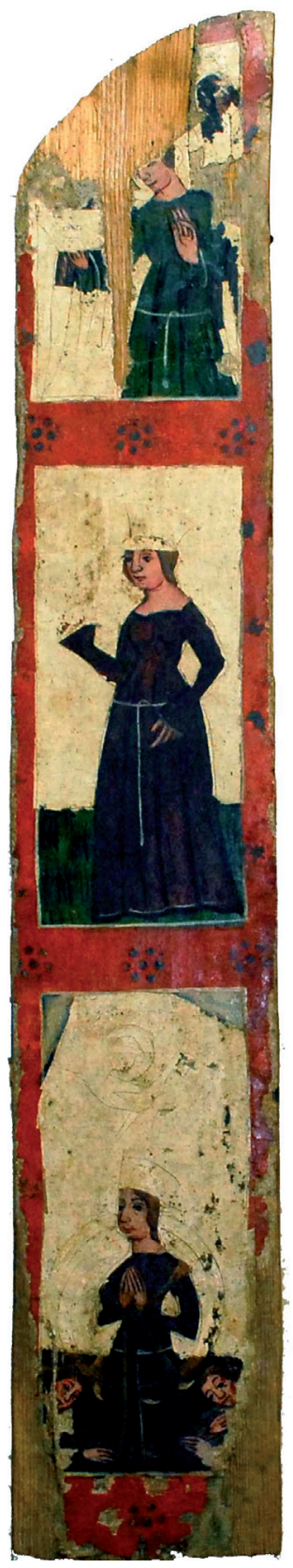

Fig. 6.

Inside of a tabernacle-altarpiece panel preserved in Sant Andreu de València d'Àneu, Lleida.

Photo: Joan Blanco.

Fig. 7 .

Outside of a tabernacle-altarpiece panel preserved in Sant Andreu de València d'Àneu, Lleida. Photo: Centre de Restauració de Béns Mobles, Generalitat de Catalunya (Carles Aymerich).

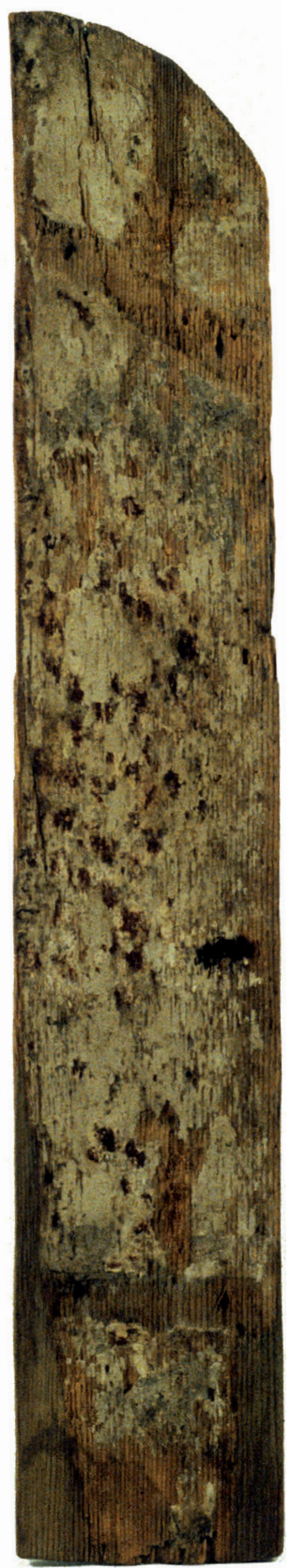



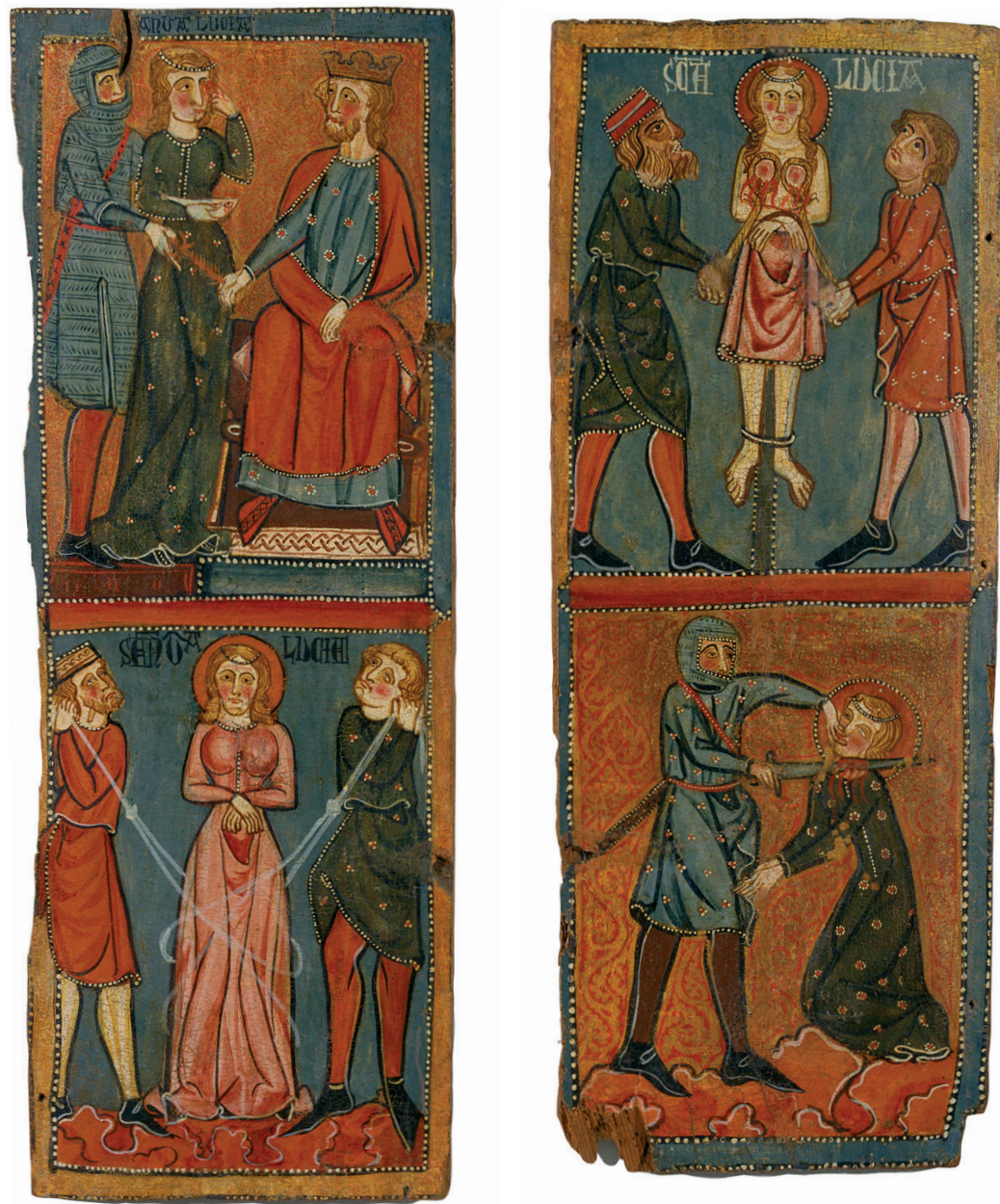

Fig. 8. Inside of two tabernacle-altarpiece panels originating from Santa Llúcia de Mur,

Museu Nacional d'Art de Catalunya, Barcelona.

Photo: Museu Nacional d'Art de Catalunya, Barcelona (2020). 


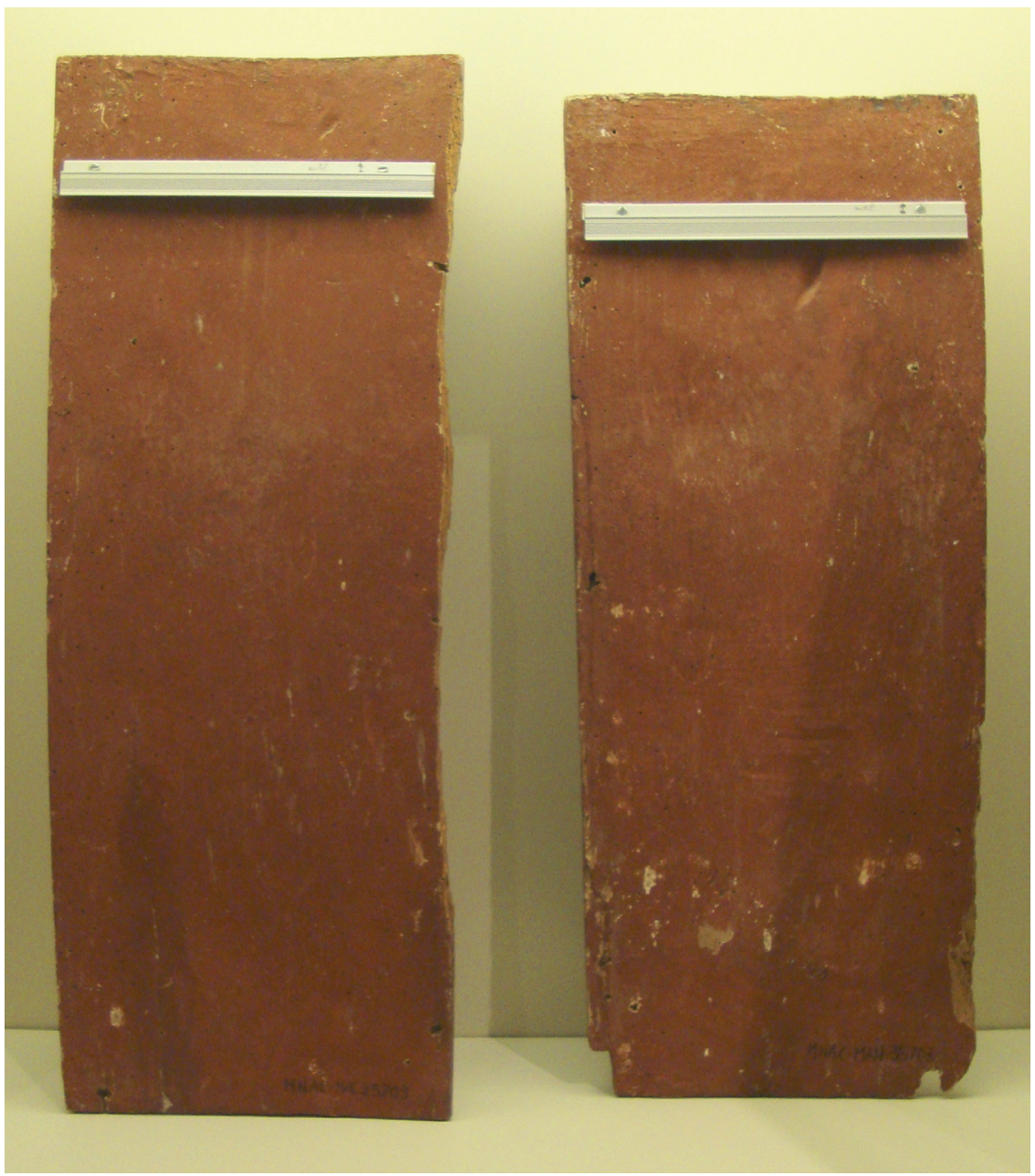

Fig. 9. Outside of two tabernacle-altarpiece panels originating from Santa Llúcia de Mur, Museu Nacional d'Art de Catalunya, Barcelona. Photo: Museu Nacional d'Art de Catalunya, Barcelona (2020). 

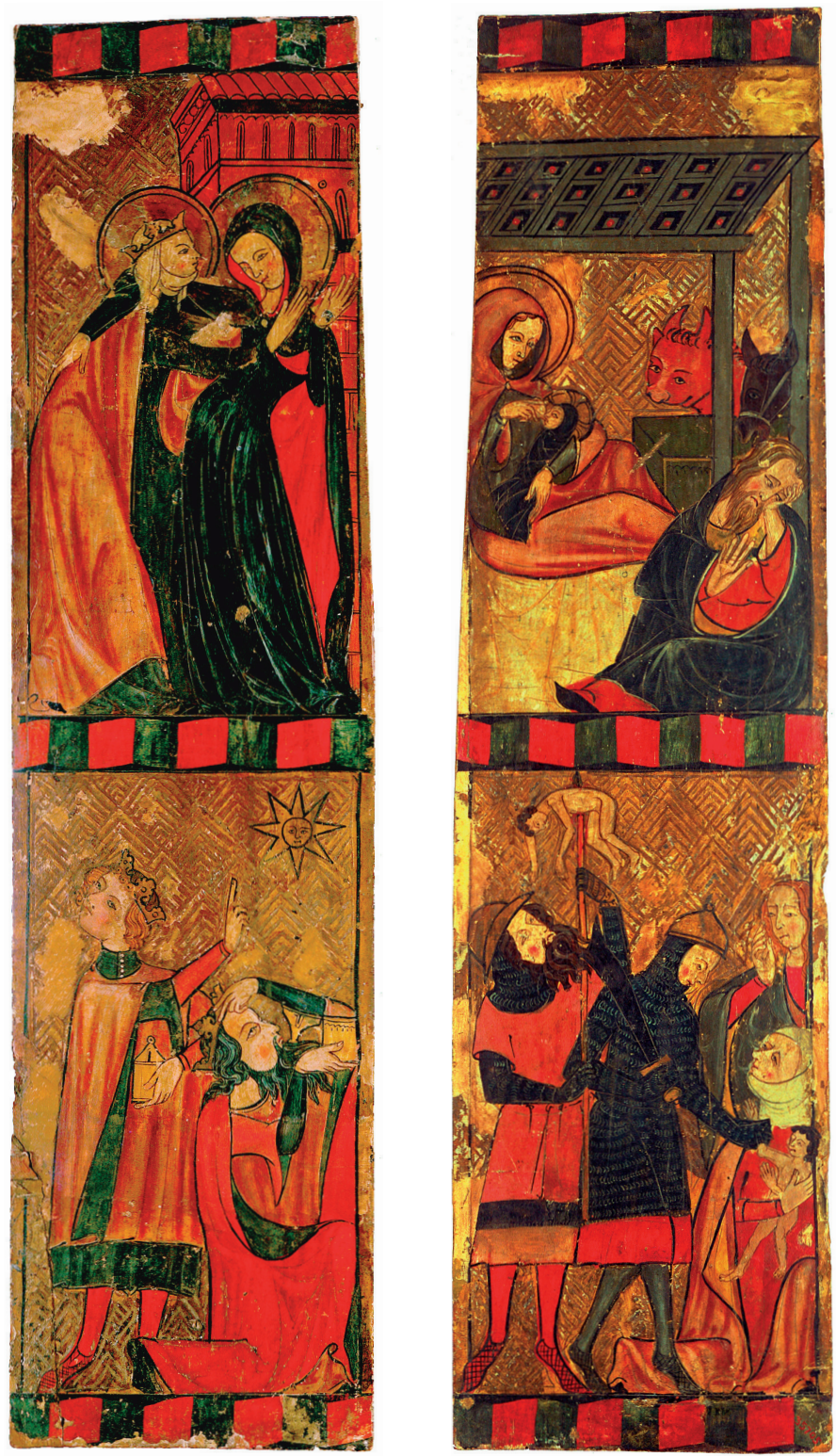

Fig. Io. Inside of two tabernacle-altarpiece panels,

Museu Nacional d'Art de Catalunya, Barcelona.

Photo: Museu Nacional d'Art de Catalunya, Barcelona (2020). 


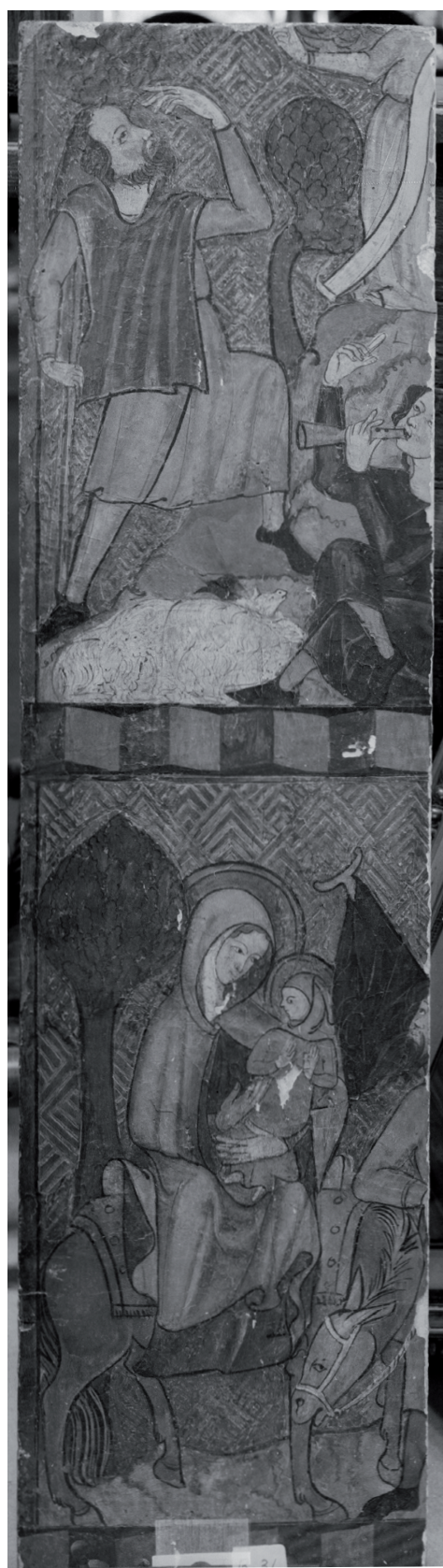

Fig. II.

Inside of a tabenacle-altarpiece panel, private collection.

Photo: (C) 2020 Institut Amatller d'Art Hispànic. 


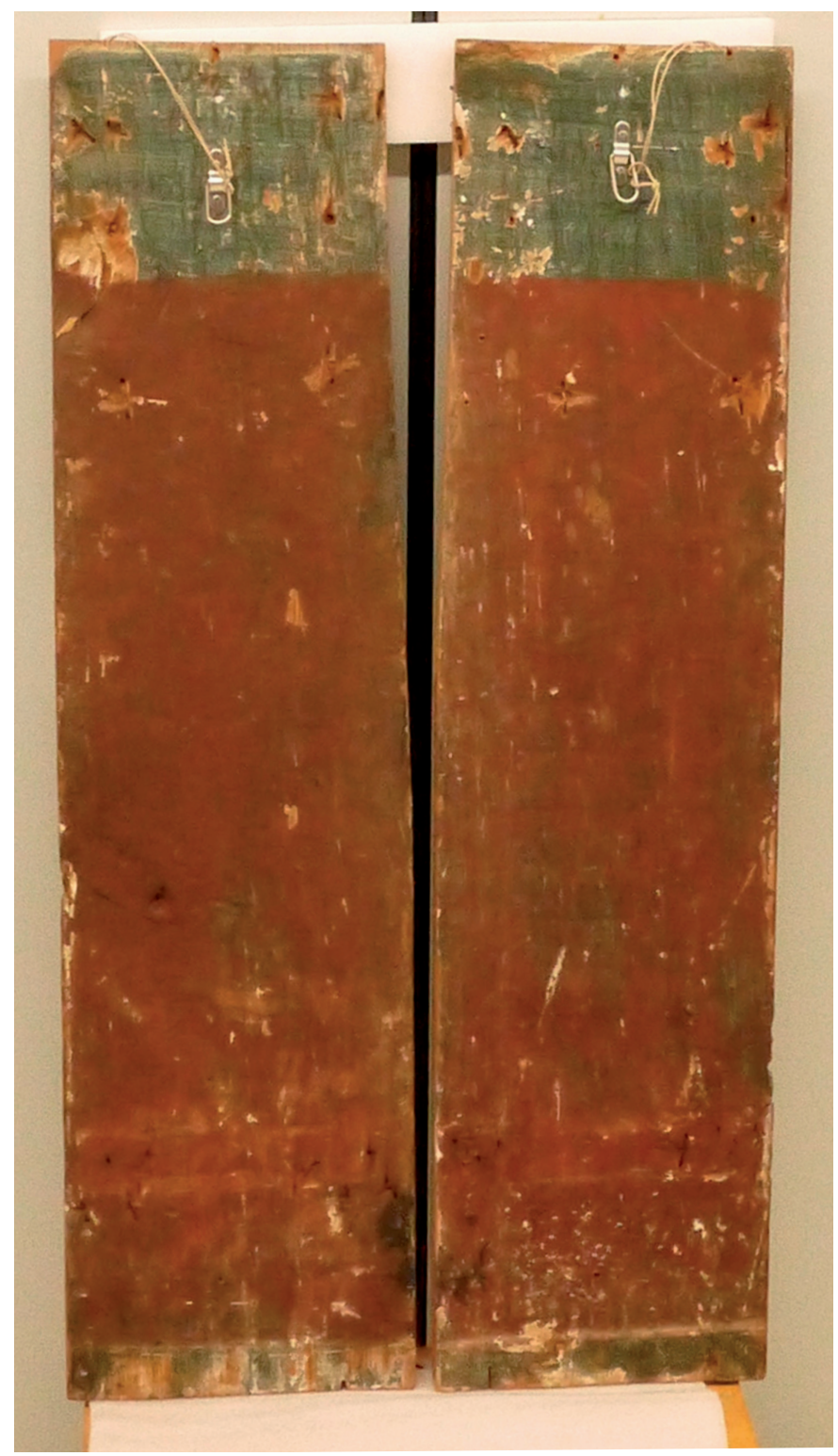

Fig. I2. Outside of two tabernacle-altarpiece panels, Museu Nacional d'Art de Catalunya, Barcelona.

Photo: Museu Nacional d'Art de Catalunya, Barcelona (2020). 


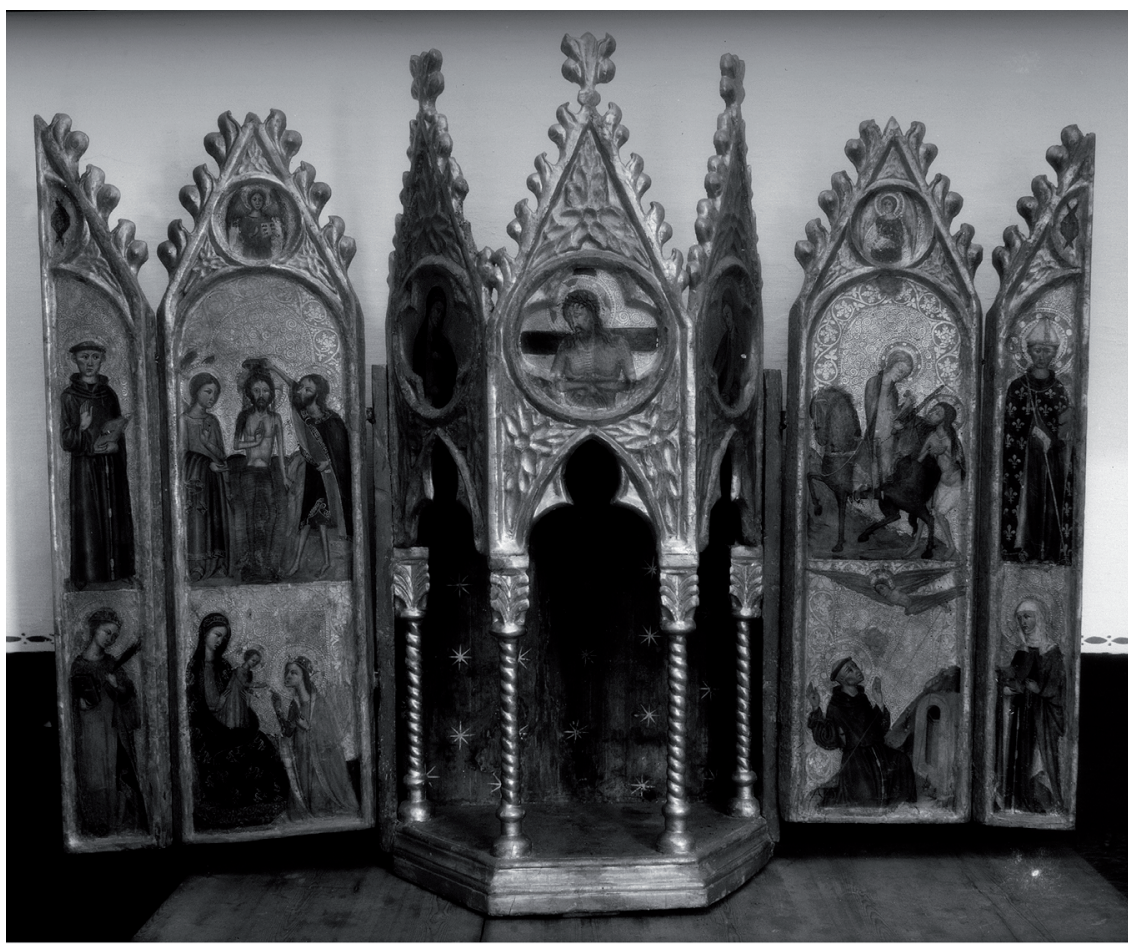

Fig. 13. Tabernacle-altarpiece

previously preserved in the Mateu collection, Barcelona.

Photo: () 2020 Institut Amatller d'Art Hispànic. 


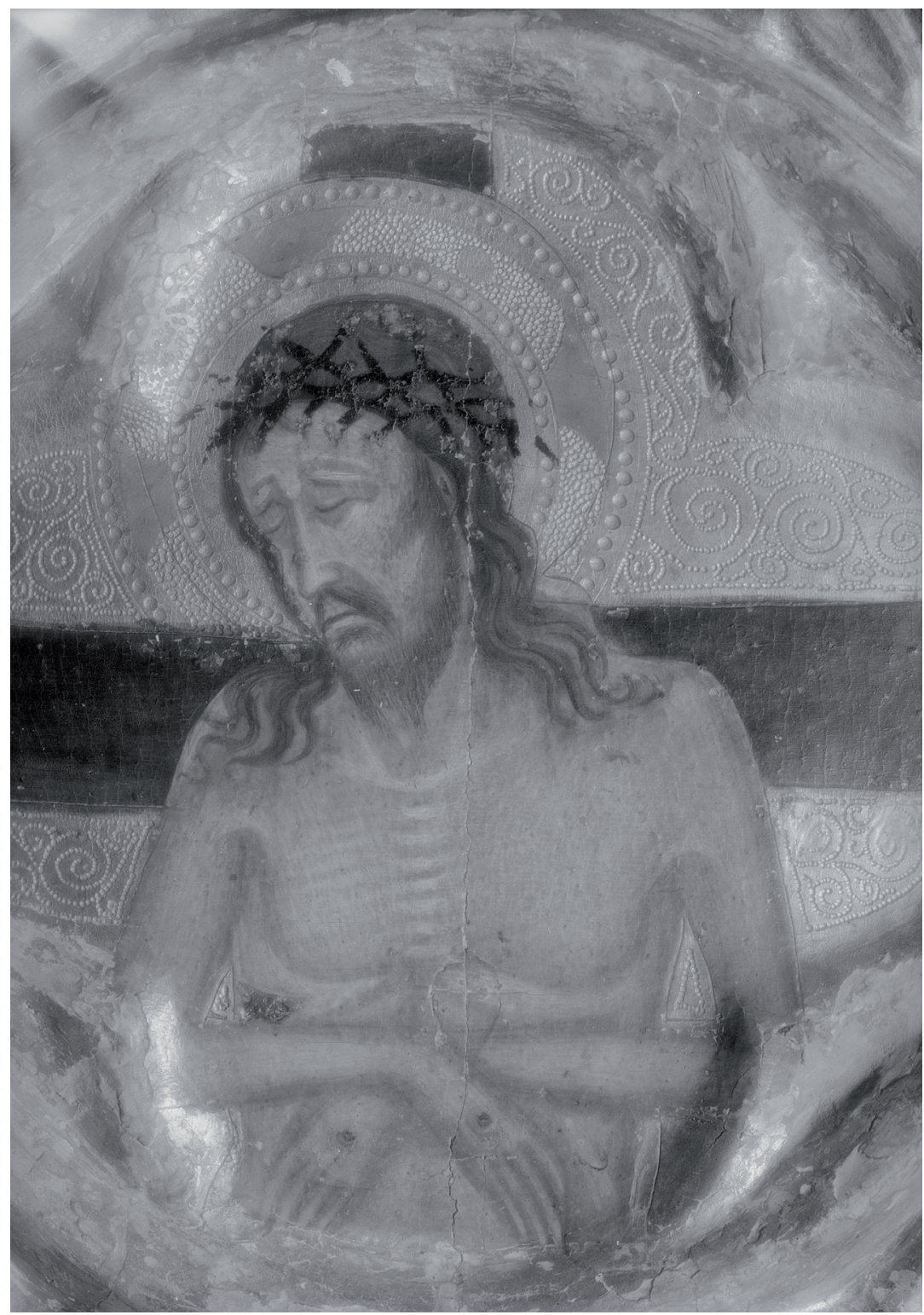

Fig. I4. Christus Patiens.

Detail of a tabernacle-altarpiece previously preserved in the Mateu collection, Barcelona. Photo: (C) 2020 Institut Amatller d'Art Hispànic. 


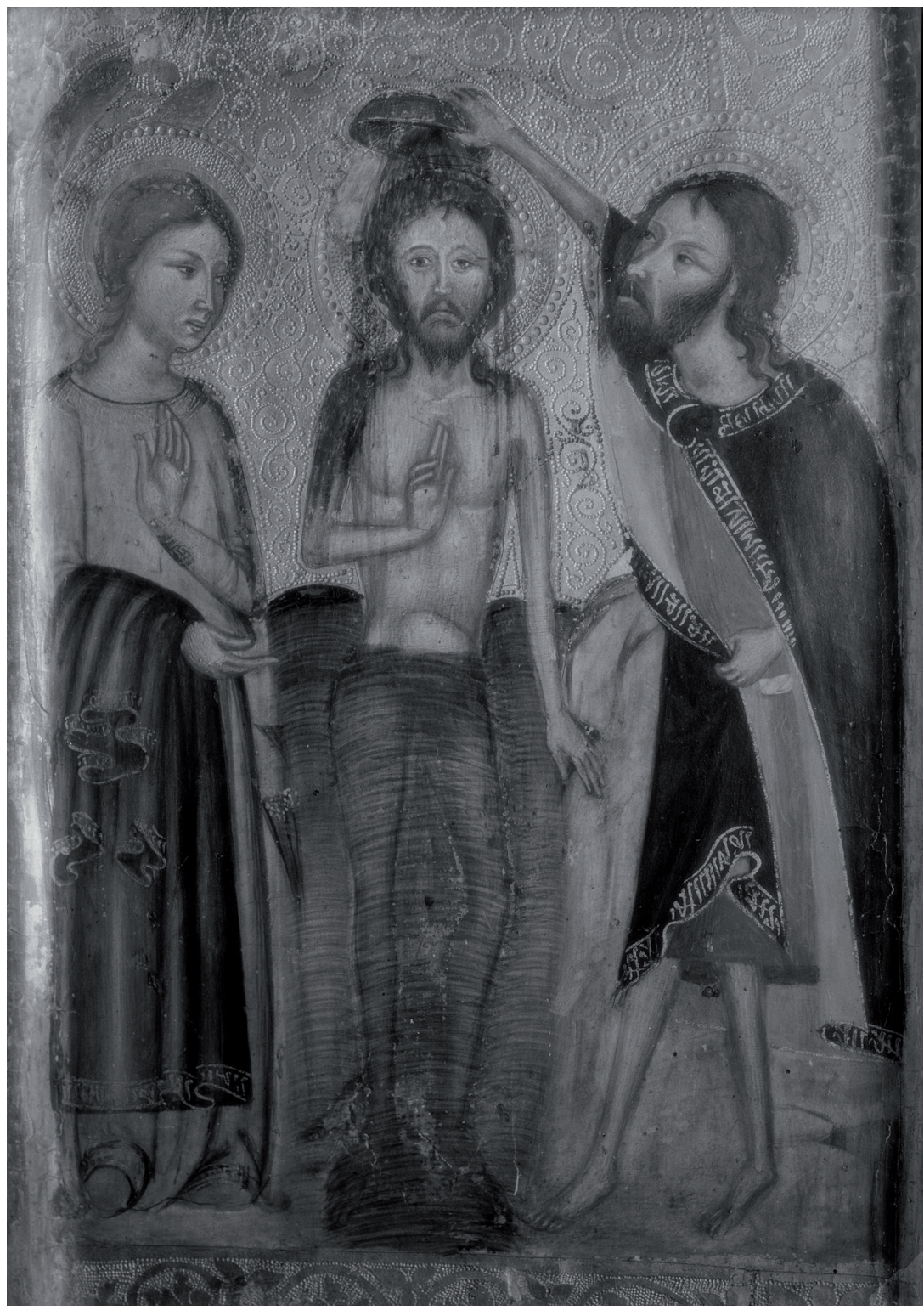

Fig. 15. Baptism of Christ. Detail of a tabernacle-altarpiece previously preserved in the Mateu collection, Barcelona. Photo: (C) 2020 Institut Amatller d'Art Hispànic. 

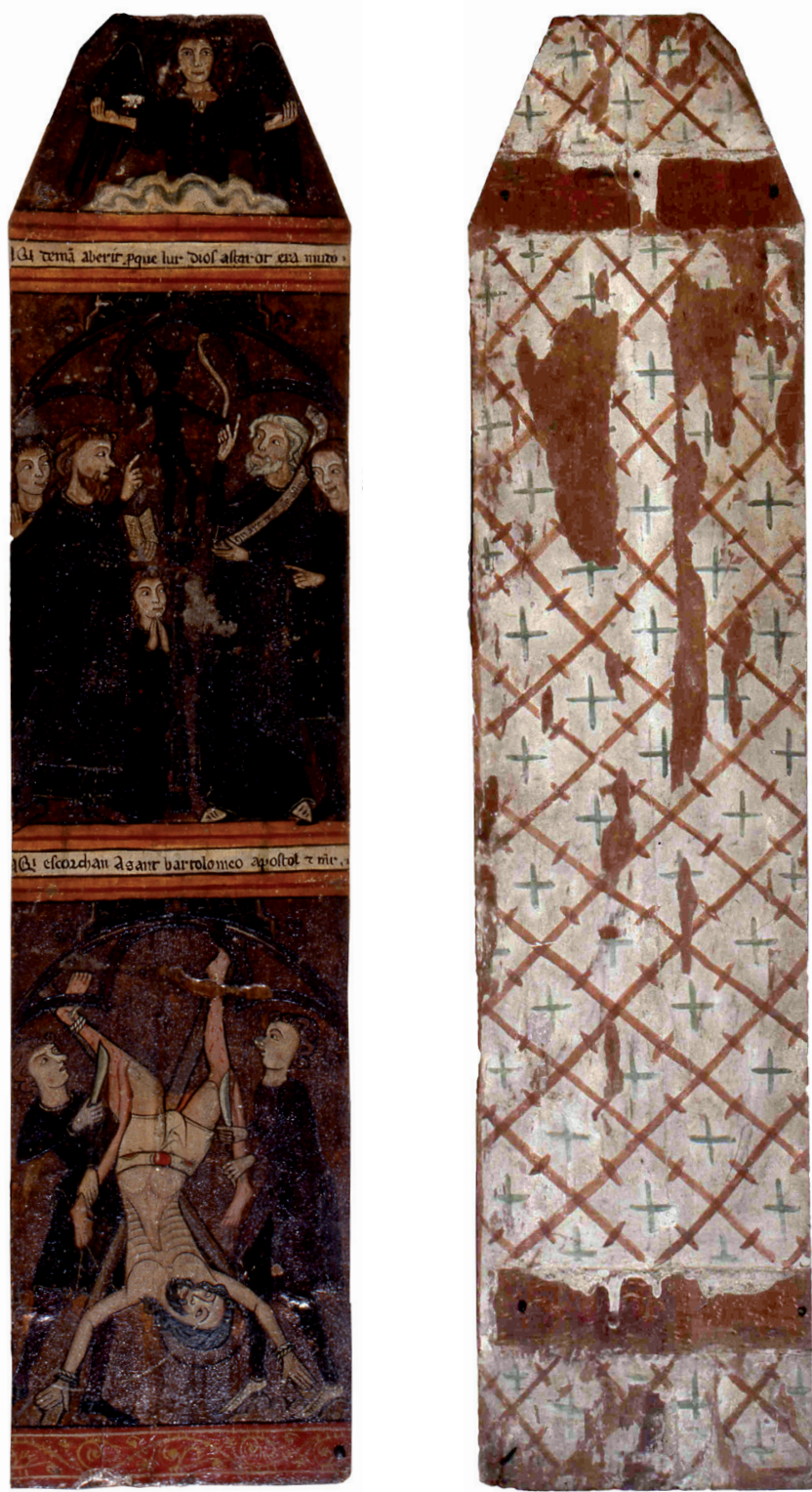

Fig. I6. Inside and outside of a tabernacle-altarpiece panel, Museu de Terrassa, Terrassa. Photo: Museu de Terrassa. 


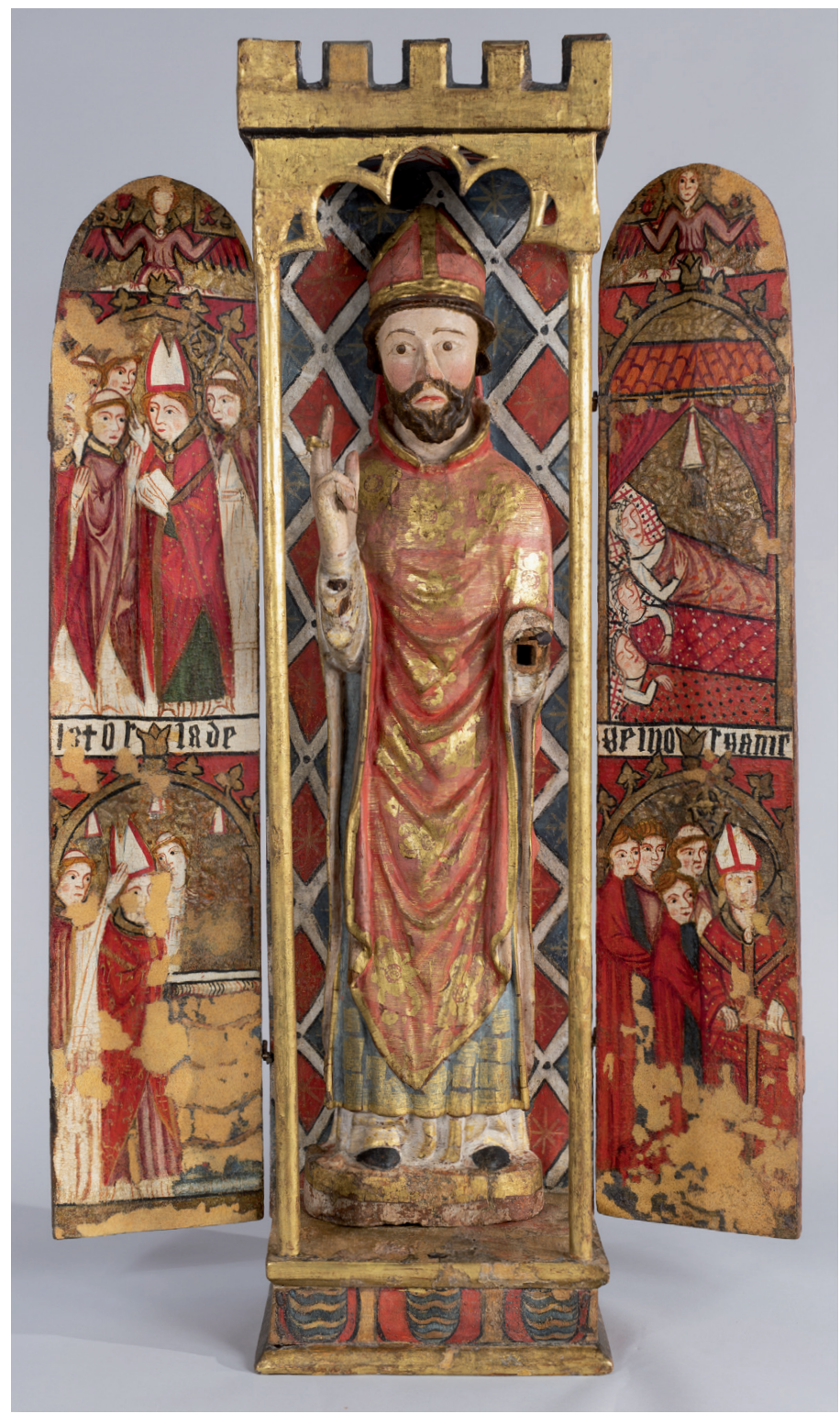

Fig. 17. Saint Nicholas tabernacle-altarpiece,

Museu Nacional d'Art de Catalunya, Barcelona.

Photo: Museu Nacional d'Art de Catalunya, Barcelona (2020). 


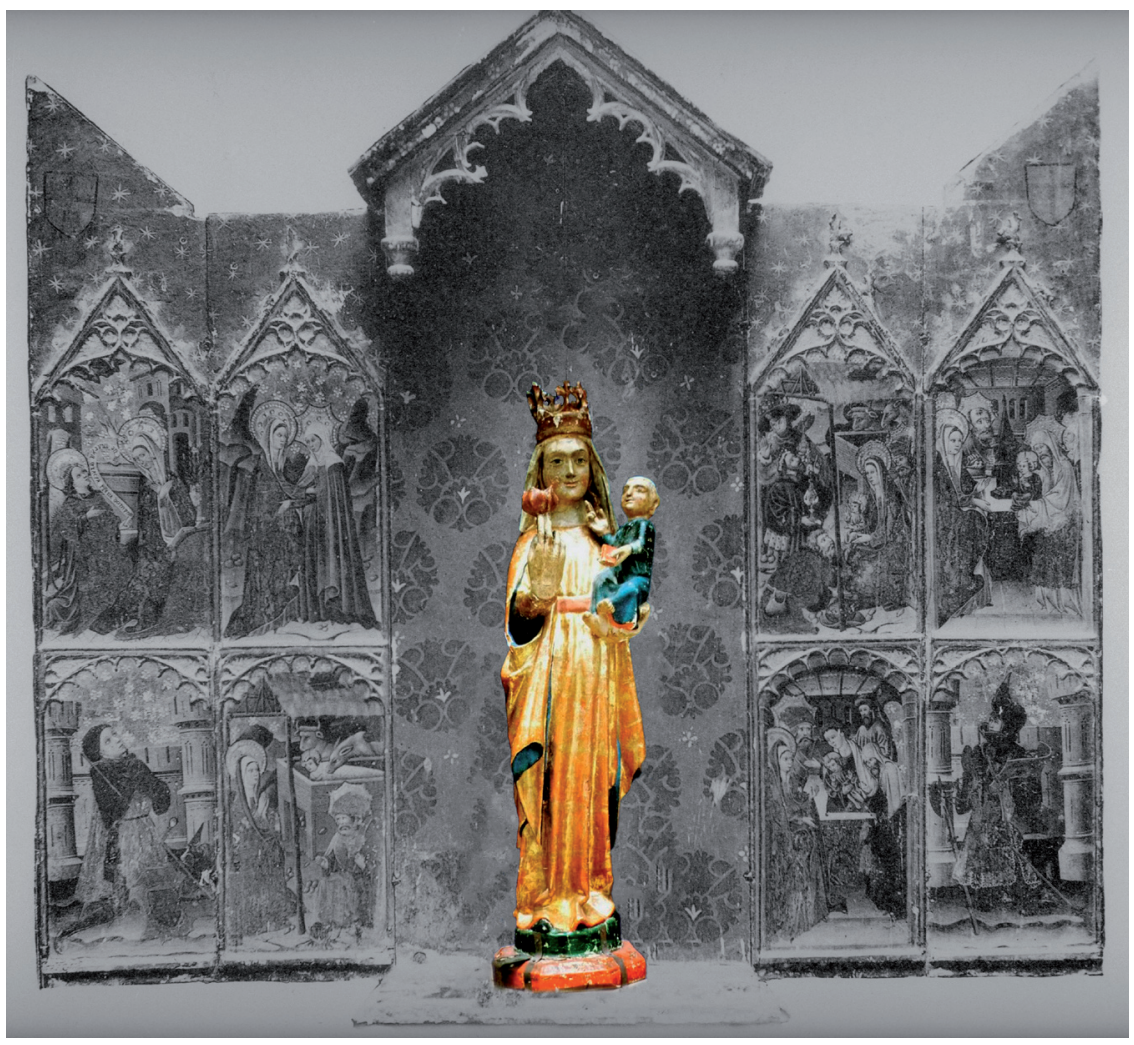

Fig. 18. Graphic reconstruction of the Belchite tabernacle-altarpiece (according to Martín, 2009). 
